\title{
Herói ou vilão? Bertolt Brecht e a crise de junho de $1953^{1}$
}

MARK W. CLARK

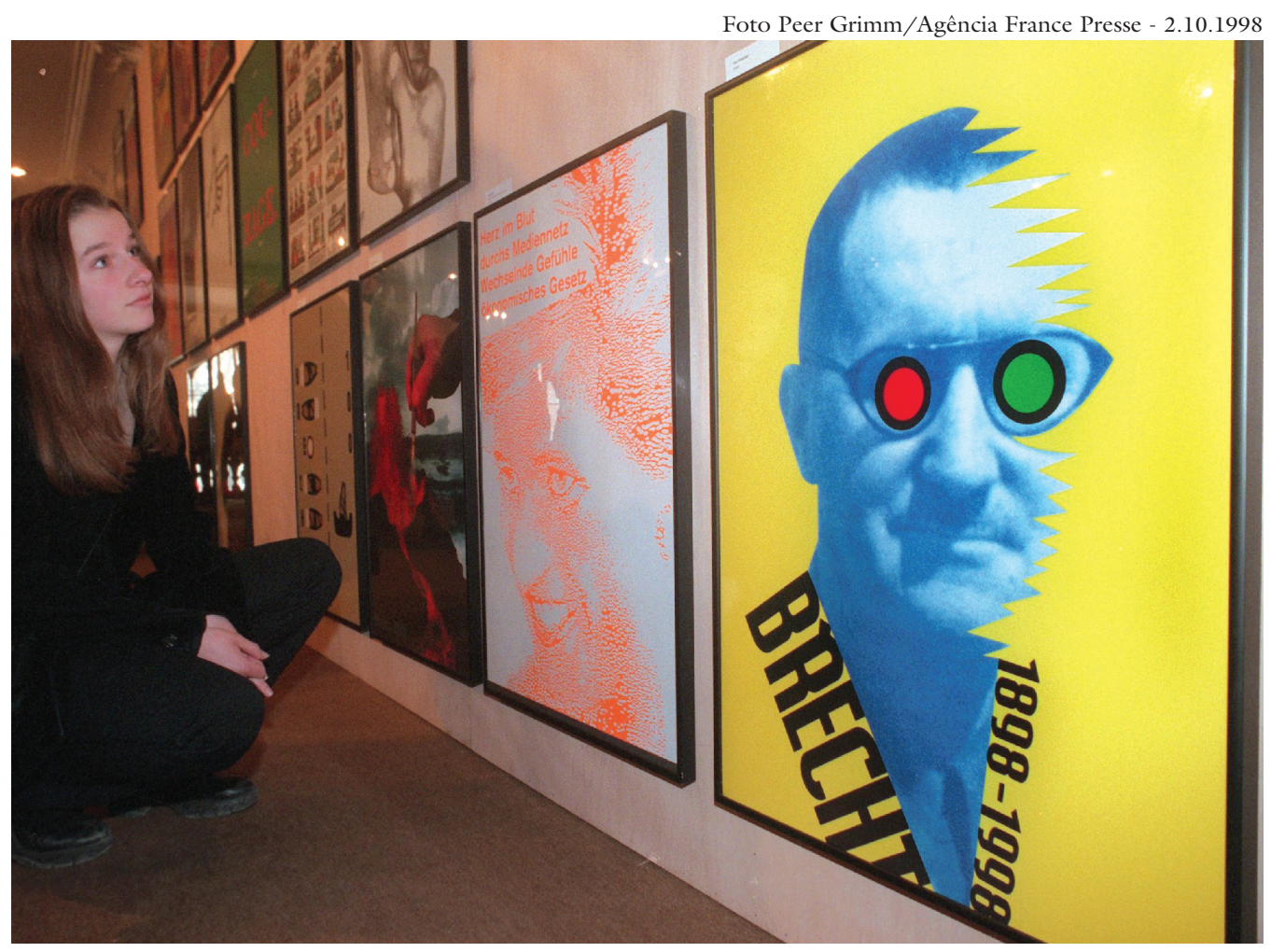

Em 1998, a Companhia Berliner Ensemble promoveu no Teatro do Schiffbauerdamm, em Berlim, uma mostra de pôsteres comemorativa do 100ª aniversário de B. Brecht (1898-1956).

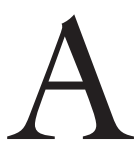

CARreIRA de Bertolt Brecht na República Democrática Alemã tem sido objeto de acirrada controvérsia desde sua morte, em 1956. Para muitos, foi durante esse período que Brecht abandonou o papel de intelectual independente para se tornar um funcionário do partido. Hannah Arendt argumentou que ele "deixou de ser um poeta" durante seus anos na RDA, sofrendo "a repentina perda daquilo que, ao longo da história humana, tem figurado como um dom divino". Essa perda ele sofreu não quando se tornou comunista, ou quando se recusou a romper com o comunismo durante os Julgamentos de Moscou, e nem mesmo quando deixou de se pronunciar publicamente sobre o Pacto Hitler-Stalin, mas apenas quando "se retirou para Berlim Oriental, onde pôde ver, dia após dia, o que significava para o povo viver sob um regime comunista" (Arendt, 1968, p.213-5). Theodor Adorno (1992, p.86) classificou Brecht como um "apologista da cumplicidade", que defendeu não um "socialismo im- 
perfeito, mas uma tirania". Especialmente depois da insurreição dos trabalhadores em 1953, quando Brecht apoiou publicamente as severas sanções do regime, muitos críticos ocidentais o descreveram como um traidor intelectual que tinha abandonado os próprios trabalhadores em nome dos quais ele alegava falar (cf. Grass, 1966).

Alguns biógrafos recentes, entre eles Ronald Hayman e John Fuegi, também fizeram ácidas críticas aos atos de Brecht durante essa crise. Na única oportunidade de derrotar a ditadura comunista e recuperar a liberdade, por covardia, oportunismo ou ambas as razões, Brecht escolheu apoiar o regime stalinista de Walter Ulbricht. Outros biógrafos foram mais compreensivos. Werner Mittenzwei, por exemplo, descreveu Brecht como uma figura quase heróica. Motivado pela preocupação com o incipiente estado comunista, ele defendeu a liberdade artística opondo-se aos funcionários do partido e liderou ações contra um regime ditatorial (Mittenzwei, 1986, v.II, p.482-541). ${ }^{2}$

Informadas com demasiada freqüência por suposições relativas à guerra fria e por uma concepção construída a posteriori sobre quais eram as possibilidades naquele contexto, essas interpretações não apresentam o quadro mais nítido da carreira de Brecht na RDA, nem de suas ações nesse momento de crise. Este artigo trata das reações de Brecht aos desafios por ele enfrentados na recém-proclamada RDA e, mais especificamente, na crise precipitada pelos fatos de 1953. Brecht era um tipo específico de intelectual alemão, alguém que se posicionava entre sua experiência de exílio no Ocidente, por um lado, e, por outro, sua convicção de que o futuro da Alemanha estava em uma sociedade socialista que, após o colapso do Terceiro Reich, só poderia ser garantida pela União Soviética. À época de seu retorno à Alemanha, Brecht concebia sua contribuição intelectual como uma mercadoria, no sentido revolucionário do termo que ele havia desenvolvido em The Three Penny Lawsuit [O processo dos três vinténs]. À medida que se ajustava às inconstantes realidades do incipiente estado comunista, ele foi aprendendo a avaliar e exercitar seu valor de mercadoria, trabalhando para construir uma nova cultura socialista sobre as ruínas da antiga alta cultura. Ao mesmo tempo, ele ajudou a iniciar uma reavaliação crítica da tradição cultural alemã e garantiu uma sede permanente para o Berliner Ensemble.

Desde a década de 1920, Brecht já era um dramaturgo conhecido e um intelectual polêmico. Hostilizando a antiga alta cultura alemã, ele buscou criar "uma arte nova, social e antimetafísica", que se afastasse significativamente da tradição burguesa do século XIX. ${ }^{3}$ Isso significava que a antiga alta cultura, com seu idealismo e elitismo, teria de ser substituída por uma cultura especificamente moderna. Brecht (1964, p.23) exigia "a transformação radical do teatro", que iria "corresponder à inteira e radical transformação da mentalidade de nosso tempo". Na década de 1920 , juntamente com Erwin Piscator, ele criou um teatro "épico" que se diferenciava do teatro "dramático" ou "aristotélico". Enquanto a premissa do teatro dramático era de que a natureza humana não podia ser mudada, o teatro "épico" supunha que ela podia mudar e já estava mudando (Brecht, 1957, v.2, p.104). 
A radicalização da teoria teatral de Brecht coincidiu com sua conversão ao marxismo. Na realidade, a idéia de que o espectador deveria aprender a considerar o mundo como algo mutável o ajudou a adaptar sua técnica literária a suas novas crenças (Brecht, 1968a, p.79). À medida que ia se comprometendo mais com o marxismo no final da década de 1920, sua atenção voltou-se mais explicitamente para a política e a arte política, e ele gravitou na direção do leninismo (Bunge, 1970, p.96-7). Ele chegou a aceitar a necessidade da luta de classes, um conceito que se transformou em componente principal de seu pensamento político e estético. Entretanto, no início da década de 1930, ele também foi influenciado por dois marxistas não-ortodoxos, Walter Benjamin e Karl Korsch. Este último ajudou Brecht a entender a inter-relação entre arte e sociedade. Ele fortaleceu em Brecht a esperança de que sua obra pudesse contribuir para uma mudança social produtiva, e essa esperança foi central para o desenvolvimento da técnica dramática de Brecht. Brecht passou a ver que a realidade deveria ser representada de tal forma que o espectador não se sentisse em casa, mas que assumisse uma posição crítica em relação a ela, a fim de ser capaz de mudá-la. ${ }^{4}$ Benjamin ajudou Brecht a entender que o modernismo nas artes era compatível com o marxismo.

No início da década de 1930, Brecht reinterpretou suas primeiras peças incluindo a tão aclamada Ópera dos três vinténs - através das lentes do marxismo, e escreveu uma série de Lehrstücke (peças didáticas), ou peças didáticas - que objetivavam ser modelos de comprometimento político para as crianças. Essas peças, em alguns aspectos demasiadamente simplistas em seu marxismo, fizeram de Brecht um alvo dos nacional-socialistas e da polícia alemã. $\mathrm{O}$ arquivo sobre Brecht em Berlim declarava que ele era um "dramaturgo e conferencista comunista", embora não fosse oficialmente um "membro do partido" (Mittenzwei, 1986, v.1, p.357). Como resultado disso, Brecht foi colocado na lista negra dos nazistas e fugiu da Alemanha um dia após o incêndio do Reichstag, quando mais de quatro mil comunistas e intelectuais de esquerda foram detidos.

Diferentemente de muitos de seus colegas comunistas, Brecht fixou-se por um tempo na Escandinávia, e mais tarde nos Estados Unidos. Viajou pela União Soviética em 1941, mas não permaneceu ali, em parte porque temia que, tal como seus amigos Carola Neher e Sergei Tretiakov, ele mesmo viesse a desaparecer no Gulag. ${ }^{5}$ Brecht sempre teve uma atitude ambivalente em relação ao comunismo soviético sob o comando de Stalin, e isso acabaria influenciando o modo como ele se posicionaria na República Democrática Alemã. Durante a década de 1930, ele disse a Benjamin: "Na Rússia, está no poder uma ditadura sobre o proletariado", embora rapidamente acrescentasse "não devemos repudiála enquanto essa ditadura ainda realizar um trabalho prático pelo proletariado" ${ }^{6}$ Entretanto, ele nunca rompeu com a União Soviética nem a criticou abertamente durante ou após seu exílio. Mesmo em particular, Brecht era ambíguo em suas críticas (Lunn, 1982, p.77). Ao longo de toda a sua vida, Brecht reconheceu várias das falhas do sistema socialista liderado por Stalin, mas, como argumenta David Pike (1985, p.232), ele acreditava que "os vícios residuais que infestavam 
o sistema eram superados por suas virtudes historicamente garantidas e acabariam sendo vencidos por elas". No entanto, em virtude de sua constante relutância em entrar para o partido, e pelo fato de mais tarde Georg Lukács tê-lo classificado como um "formalista", Brecht desenvolveu uma reputação de comunista não-ortodoxo. Por um lado, sua reputação como uma voz independente o fez objeto de suspeita, principalmente entre os stalinistas radicais; por outro, essa mesma reputação o tornou mais aceitável para muitos intelectuais de esquerda que nem sempre aprovavam o programa do partido.

Foi durante seu exílio - seu período criativo mais importante - que Brecht escreveu suas grandes peças, incluindo Galileu, Mãe Coragem e A boa alma de Setsuan. Também durante a década de 1930, Brecht refinou sua estética marxista, opondo-se em parte a outros pensadores socialistas - particularmente Lukács. A polêmica entre Lukács e Brecht dizia respeito a como tratar adequadamente a tradição cultural e a teoria dramática. Enquanto Lukács tinha atacado o modernismo e defendido a necessidade de um "realismo socialista", estritamente definido, Brecht insistia em uma definição mais aberta. ${ }^{7}$ Lukács (1981, p.45-75) se concentrava no realismo do século XIX e rejeitava o modernismo porque ele não tinha um senso de totalidade e perspectiva, e, dessa forma, apenas refletia o caos e a alienação do capitalismo. Além disso, como o modernismo era a expressão de artistas de vanguarda, ele não conseguia atingir as massas. Lukács atacava Brecht por ser um "formalista", por usar técnicas modernistas como a montagem; ele criticava especialmente as Lehrstücke de Brecht que, segundo ele, ficavam muito aquém do realismo. ${ }^{8}$

Brecht respondeu a Lukács em uma série de ensaios escritos para o jornal Das Wort, mas que só foram publicados após a sua morte em 1956 (Knopf, 1984, p.491-4). Lukács, argumentava Brecht, tinha ignorado as possibilidades realistas inerentes à arte moderna. $\mathrm{O}$ realismo significava "desnudar a rede causal da sociedade / evidenciar o ponto de vista dominante como o ponto de vista dos dominadores / escrever do ponto de vista da classe que preparou as soluções mais abrangentes para os problemas mais graves que afligem a sociedade humana / enfatizar a dinâmica do desenvolvimento / e do concreto para encorajar a abstração" (Brecht, 1964, p.107-9). Brecht defendia a experimentação artística argumentando que a inconstante realidade social podia ser desmascarada usando-se novas técnicas artísticas formais. Essas técnicas, que incluíam a montagem e a alienação, não estavam mais ligadas a uma classe do que estavam outras "forças de reprodução"; elas poderiam, dessa forma, ser usadas para objetivos progressivos (GKBA, v.22.2, p.628-30). Era necessário "fazer um uso atraente de todos os meios, tanto antigos quanto novos... para colocar a realidade viva nas mãos das pessoas vivas, para que ela possa ser dominada”. 9

A característica mais significativa da arte no mundo moderno era sua condição de mercadoria. Como apontou Brecht em seu ensaio "The Three Penny Lawsuit - A Sociological Experiment" [ "O processo dos três vinténs - um experimento sociológico"], a arte não era um "fenômeno de natureza social in- 


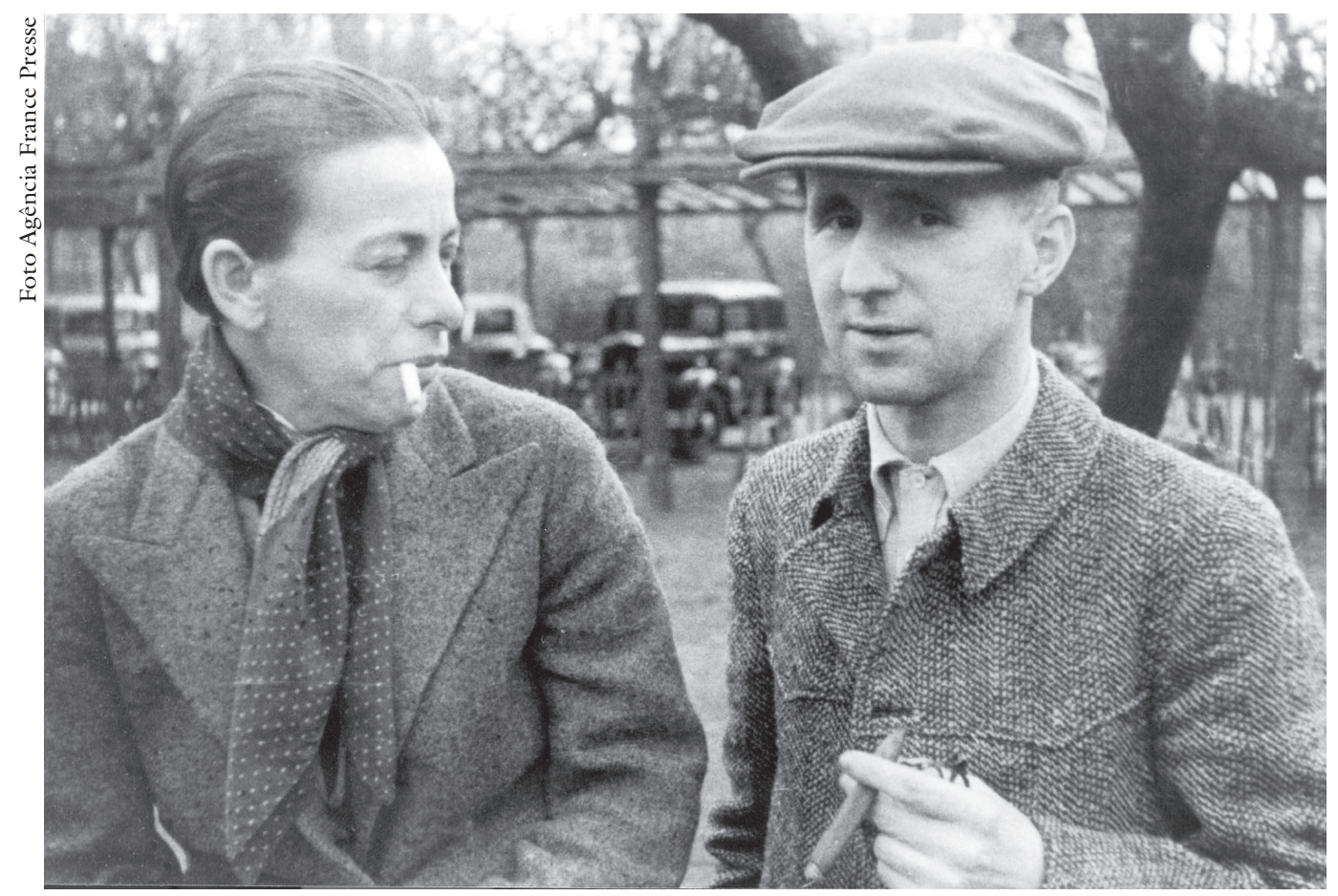

Brecht com sua esposa, a atriz alemã Helene Weigel, em Copenhague, Dinamarca, em 1936.

dependente, que pode impor-se contra a sociedade", mas apenas outra "força produtiva". "Uma obra de arte", afirmava ele, "assume imediatamente a forma de mercadoria [commodity] ... aparece separadamente do inventor em uma forma determinada pelas possibilidades comerciais do mercado". Sendo um "processo progressivo", a condição de mercadoria poderia "ser afirmada desde que o progresso seja concebido como o ato de avançar e não como o resultado passivo desse avanço. Em outras palavras, a fase de commodity também deve ser considerada superável, por sua vez, pelo avanço contínuo". Brecht continuava mantendo, entretanto, que a arte, embora não privilegiada no sentido tradicional, tinha de permanecer autônoma. A própria arte tinha o poder de transformar uma determinada realidade, desenvolvendo o pensamento dialético, desmistificando a realidade social e "antecipando" um sistema socioeconômico alternativo (Silberman, 2000, p.50, 27, 51, 163, 179-80, 195; Brecht, 1968a, p.121-3).

À medida que Brecht foi refinando sua estética, também desenvolveu uma concepção mais clara do papel dos artistas e intelectuais na sociedade. Por muito tempo, ele se opusera à suposição idealista de que os intelectuais eram árbitros apolíticos dos valores universais (Zuckmayer, 1966, p.379). Agora, sua crítica estava mais afiada, pois ele percebera que intelectuais tinham sido cúmplices da ascensão dos nazistas ao poder. Para Brecht, houvera apenas um tipo de intelectual no passado: o "reacionário" ou intelectual burguês, que "se mesclava à classe dominante", comprometia-se apenas com a arte pela arte, e servia apenas aos interesses da elite. Além disso, os intelectuais burgueses tinham direta ou indiretamente apoiado o regime semi-autocrático do Kaiserreich (Brecht, 
1968a, p.86, 88, 90). Especialmente problemática para Brecht foi a traição cometida pelos intelectuais alemães durante a República de Weimar. Na opinião de Brecht, os intelectuais - pelo menos os que tinham corrompido e malversado o intelecto - eram em grande medida responsáveis pelo declínio da República de Weimar e pela vitória dos nazistas. ${ }^{10}$ Embora inicialmente concebesse sua crítica dos intelectuais como um romance, Brecht só completou o projeto em 1953, na forma de uma peça - Turandot - e em circunstâncias muito diferentes (Knopf, 1984, p.399-418). Entretanto, elementos de sua crítica podem ser encontrados em outros lugares, incluindo as peças Galileu e Der Hofmeister, e o conto "Das Experiment".

Para Brecht, a situação daquele momento exigia um tipo diferente de intelectual, um "intelectual revolucionário", que livremente escolheria abraçar a "luta de classes". O intelectual revolucionário deveria ser "dinâmico, político e fulminante" para "esvaziar a ideologia burguesa", "intensificar a luta de classes" e "além disso desenvolver a teoria em estado puro". ${ }^{11}$ Brecht também passou a compreender seu próprio papel de uma maneira específica. Ele estava, como outros intelectuais de origem burguesa, trabalhando em prol dos interesses do proletariado. Nesse ponto, existe uma notável semelhança com a noção de Antonio Gramsci (1971, p.6-22), segundo a qual, por um tempo "intelectuais tradicionais" devem assumir os interesses do proletariado até que "intelectuais orgânicos" originados das classes trabalhadoras possam suplantá-los. Em um registro especialmente pungente de seu diário, escrito em 1940, Brecht observa:

As pessoas hesitam em chamar poetas como Hasek, Silone [O-Casey], e eu de burgueses, mas isso está errado. Nós podemos tornar nossas as preocupações do proletariado; por um certo período de tempo podemos até ser os poetas do proletariado... Em determinadas fases do desenvolvimento, quando o proletariado venceu mas ainda continua sendo proletário, a função do defensor burguês... será formalista. Depois disso, os novos poetas e soldados entram em cena. Eles encontram nas obras de seus predecessores - nossas obras - não só o meio mais altamente desenvolvido de expressão, mas também os elementos da nova cultura... Também importante em nosso trabalho é a técnica do novo começo, desenvolvida por aqueles que dominarem a tradição, porque o novo começo que não domina a tradição acaba facilmente dominado por ela. (Brecht, Arbeitsjournal, p.143)

Brecht entendeu melhor seu próprio papel intelectual como uma mercadoria. As novas tecnologias do capitalismo tinham alterado radicalmente a produção artística e, assim, descartado as velhas concepções de "arte" e "gênio artístico". O autor era "arrastado para o interior do processo técnico, [que é] visto como produção de mercadoria" (Brecht, 2000, p.143). Embora fosse consciente e profundamente orgulhoso da própria criatividade, Brecht também reconhecia que seu trabalho e reputação tinham um valor de mercado, e pensou muito sobre como instrumentalizá-los para fins específicos - principalmente nos anos cruciais entre 1949 e 1953. 
Quando Brecht voltou à Zona Soviética de Ocupação, estava numa situação singular. Sua experiência no Comitê de Atividades Antiamericanas em 1948 tinha fechado para ele todas as possibilidades na zona americana de ocupação. ${ }^{12}$ Entretanto, Berlim Oriental era especialmente atraente por vários motivos, sobretudo pela oferta de ter seu próprio teatro e pela presença de muitos amigos emigrados em quem ele confiava, entre eles Johannes R. Becher, o principal agente cultural do governo de Berlim Oriental. ${ }^{13}$ Durante uma longa viagem pelo setor soviético de Berlim no final de 1948, Brecht entabulou discussões com muitas das mais importantes figuras políticas e culturais da Zona Soviética: Becher, Wolfgang Langhoff (diretor do Deutsches Theater) e Alexander Dymschitz, agente cultural do governo soviético. Apesar de algumas apreensões, durante essa visita ele teve reforçadas suas certezas de que apenas a União Soviética poderia garantir da melhor forma possível a Alemanha socialista com a qual ele sonhava (Brecht, Arbeitsjournal, p.849). Sem dúvida, ele ainda conservava sentimentos ambivalentes em relação ao comunismo ao estilo soviético. Ele não tinha dúvidas de que iria se opor a marxistas e stalinistas dogmáticos, e isso provavelmente lhe trazia alguma ansiedade. Entretanto, Brecht também reconhecia que haveria um grupo suficientemente grande de pessoas que pensavam como ele e que o ajudariam a resistir aos mais dogmáticos, e ele sabia que sua reputação era grande o bastante para protegê-lo. Apesar dos problemas e desafios, talvez até por causa deles, esse foi um "ótimo período para a arte" (GKBA, v.23, p.129).

Quando Brecht retornou para a Alemanha, ainda havia alguma abertura na vida cultural da RDA. Embora David Pike tenha argumentado que a sorte estava lançada para uma ditadura ao estilo stalinista, e também para as políticas culturais concomitantes, mesmo antes da separação da Alemanha, Gerd Dietrich demonstrou que continuou a existir algum espaço de manobra na política cultural até meados da década de 1950, quando a situação política tornou-se muito mais restritiva. ${ }^{14}$ Haveria janelas de oportunidades, especialmente em 1953, durante o desequilíbrio que se seguiu à morte de Stalin.

Desde o início da ocupação, os soviéticos e o SED (Partido da União Socialista da RDA) tinham reconhecido a importância da esfera cultural e dos intelectuais. Para funcionários do governo, tais como Becher, era necessário extirpar a intra-estrutura cultural do Nacional-Socialismo e reconstruir a cultura sobre uma base democrática. ${ }^{15}$ Dessa forma, Becher ajudou a criar a Kulturbund zur demokratischen Erneuerung, cujos objetivos eram "a produção ativa na área da literatura, da ciência e da arte para a destruição intelectual e moral do nazismo, a participação no renascimento intelectual do povo alemão visando à democracia e ao progresso, o encorajamento da pesquisa científica livre e de toda a vida cultural, a popularização da herança clássica da vida intelectual alemã". ${ }^{16}$

O desafio colocado para os intelectuais, bem como as oportunidades disponíveis eram significativamente diferentes em relação aos dos anos de exílio. Conseqüentemente, Brecht começou a reconsiderar seu papel de intelectual. Ele não produziu nenhum texto teórico durante esse período, mas refinou ain- 
da mais sua concepção de responsabilidade intelectual à medida que respondia aos desafios do pós-guerra. Como Becher, Brecht estava convencido de que os intelectuais tinham de desempenhar um papel decisivo na transformação da Alemanha durante aquele momento de crise. Esse processo exigia mais do que constituir um estado; exigia a criação de uma comunidade, e a cultura era essencial para esse processo. Entretanto, para que uma nova cultura socialista se desenvolvesse, deveria haver certa liberdade, especialmente para artistas e intelectuais. Eles não podiam simplesmente ser os porta-vozes da propaganda política do partido. Segundo Brecht disse a Wolfgang Harich em 1951, a função da arte em um tempo de luta era servir como propaganda do partido. Entretanto, "a exigência das obras de arte para nós é ainda mais alta: conteúdo e forma" (BBA, $1340 / 55)$. Essa visão o colocava em conflito com os dirigentes do SED, mas Brecht nunca fugiu do conflito ou da crítica. Ele acreditava que uma crítica eficaz era parte integrante da construção de uma nova cultura socialista, por meio da qual os valores e as aspirações da classe trabalhadora poderiam ser expressos.

Brecht ainda acreditava que sua mais importante contribuição era artística, e sua prioridade foi sempre o teatro. No teatro ele poderia fazer a melhor contribuição para uma nova sociedade e identidade socialista. Peter Huchel (1984, p.375, 151-2) posteriormente relembrou que, para Brecht, "o teatro era a coisa mais importante; pelo teatro ele fazia acordos". Mas ele também reconheceu que podia - e devia - exercer um tipo mais direto de influência política valendose de sua posição de agente cultural. Entretanto, ele nunca desejou tornar-se um político profissional ou subordinar-se ao aparelho do estado, o que na sua consciência the teria negado seu valor de mercadoria. Gradualmente, à medida que ganhava experiência política, Brecht foi descobrindo a melhor maneira de influenciar a política cultural para conseguir o que queria. Isso geralmente significava trabalhar nos bastidores, valendo-se de sua posição como membro da Academia das Artes, da qual ele se tornou sócio-fundador em $1949 .{ }^{17}$ Era crucial que a Academia controlasse a produção artística $e$ a política cultural (GKBA, v.23, p.126). Embora geralmente ele não estivesse disposto a criticar o partido abertamente em um fórum público - e nunca estivesse disposto a criticar para o Ocidente as políticas da RDA -, ele estava preparado para defender suas posições nas questões cruciais, especialmente nos bastidores. Mas ele escolhia cuidadosamente suas batalhas. Como afirmou Manfred Jaeger (1973, p.169): "Ele sabia que estava no meio de uma revolução social, na qual desejava introduzir determinadas mudanças - que eram difíceis mas não fúteis; arriscadas, mas não impossíveis".

O fato de Brecht ter recebido apoio estatal para sua companhia de teatro imediatamente após a sua volta ilustra a grande importância que os soviéticos e o SED lhe atribuíam. Ele não causou desapontamentos. O Berliner Ensemble depressa se tornou a principal atração e uma carta na manga - na verdade, foi uma das pouquíssimas realizações culturais de toda a República Democrática Alemã. Muito por causa de sua reputação e o rápido sucesso de seu teatro, do qual a 


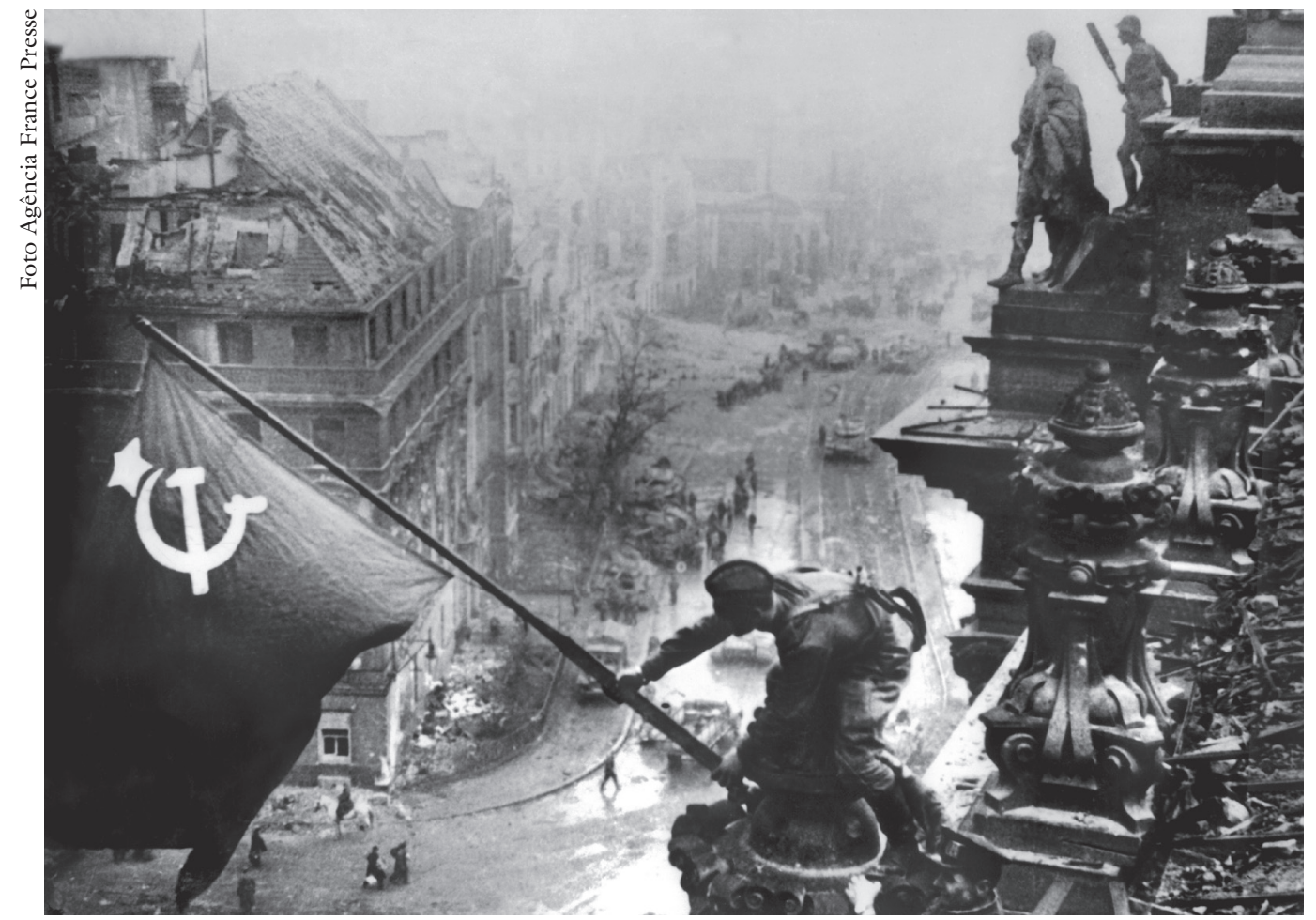

Os russos ocupam Berlim em 2 de maio de 1945: soldado levanta a bandeira sobre o Reichstag.

estréia de Mãe Coragem em janeiro de 1949 em Berlim é apenas o exemplo mais destacado, Brecht desfrutava de privilégios que não estavam disponíveis para a maioria dos intelectuais da Alemanha Oriental - incluindo, no final, um carro, duas casas e liberdade para viajar para fora da RDA. Ele também se precatou, e manteve seu status de mercadoria, garantindo para si um passaporte austríaco, uma conta em um banco suíço e um editor na Alemanha Ocidental. Assim, ele tinha um grau de independência que poucos outros possuíam. Entretanto, nem essas vantagens nem sua filiação à Academia das Artes proporcionaram a Brecht plena liberdade na RDA. Por exemplo, somente em 1954 sua companhia de teatro pôde ter uma sede fixa, o Theater am Schiffbauerdamm. Além disso, estava sempre à mercê da elite do partido para conseguir financiamentos estatais, distribuição de ingressos e resenhas de suas peças nos jornais do partido.

Muitos membros do partido tinham fortes suspeitas em relação a Brecht em virtude de sua reputação de formalista e do fato de ele não ter passado o período do exílio em Moscou. Entre seus mais eminentes críticos estava Walter Ullbricht, que desconfiava dele e até recomendou a intelectuais como Wilhelm Girnus, editor do jornal do partido Nenes Deutschland, que ficassem de olho nele. Mas Ullbricht também entendia que Brecht conferia credibilidade ao regime e o tolerava razoavelmente. Brecht reconhecia isso e enfatizava sua reputação internacional em todas as oportunidades, a fim de garantir e manter sua posição. Outro opositor importante era Fritz Erpenbeck, editor do Theater der Zeit e posteriormente diretor do Comitê Central do Programa do Ministério para a 
Cultura Nacional. Erpenbeck manifestara essa sua disposição em 1949, quando acusou Brecht de uma recaída na direção do formalismo em Mãe Coragem. Entretanto, Brecht também sempre teve amigos e aliados importantes no partido, dos quais o mais destacado era Becher. Esse, juntamente com vários intelectuais como Wolfgang Harich, ajudou a promover a carreira e as causas de Brecht. Na verdade, eles algumas vezes chegaram a pôr em risco suas próprias carreiras para proteger Brecht.

Além do rápido triunfo de Mãe Coragem, Brecht também alcançou outros sucessos, entre eles a adaptação da peça de Jacob Lenz, Der Hofmeister - sua primeira tentativa pós-guerra de avaliar a tradição intelectual alemã. Brecht acreditava que para se transformar a Alemanha teria de se distanciar de suas tradições mais antigas e malsãs, especialmente a tradição intelectual, que ele acreditava ser em grande medida responsável pela "miséria alemã". Ambientada na Prússia e na Saxônia após a Guerra dos Sete Anos, a peça examina a desastrosa carreira e a emasculação de um aspirante a intelectual, Läuffer. De acordo com Brecht, Der Hofmeister era uma sátira "do período em que a burguesia alemã construiu seu sistema de educação" ( $G K B A$, v.24, p.392). A história não era "puramente simbólica; na realidade, a auto-emasculação dos intelectuais é apresentada por meio de um exemplo de carne e osso... A castração física não apenas significa a autoemasculação intelectual, mas é representada como uma saída grotesca para a situação social de Läuffer" (cf. Willett, 1990, p.491-2). Além de sua impor-tância histórica, a peça mostrava por que os intelectuais alemães tinham sido incapazes de resistir à ameaça nazista. Hofmeister estreou em 15 de abril de 1950 e foi bem recebida tanto no mundo oriental quanto no ocidental. Paul Rilla (1950) observou que a peça era uma "interpretação brechtiana" e não o Hofmeister de Lenz, mas mesmo assim era "uma produção extraordinária e exemplar". Até mesmo Erpenbeck teve uma impressão positiva. ${ }^{18}$

Se Brecht teve alguns sucessos, ele também enfrentou reveses durante seus primeiros três anos na Alemanha Oriental, entre os quais se destaca a produção da ópera Das Verhör des Lukullus. Ambientada na Roma clássica, a trama gira em torno do julgamento do general romano Lucullus, realizado no mundo dos mortos por um camponês, um escravo, uma vendedora de peixe, um padeiro e uma cortesã. Embora reconheçam as grandes vitórias do general, eles por fim o condenam por ter sacrificado oitenta mil homens e o sentenciam a ser jogado no precipício. A controvérsia em relação à ópera girou em torno de duas acusações principais: pacifismo e formalismo. Os funcionários do SED interpretaram a condenação de Lucullus como uma condenação de guerra em geral, que não fazia distinção entre guerras de defesa e guerras de agressão - uma postura que, naquele momento, era inaceitável no bloco Oriental. A acusação mais grave de formalismo se dirigia principalmente a Paul Dessau, colaborador musical de Brecht. Mesmo antes da primeira encenação, Ernst Meyer criticou severamente a ópera, relatando ao Secretariado do Comitê Central que ela continha "todos os elementos do formalismo, exibidos por meio da predominância de dissonân- 
cias destrutivas e corrosivas, e de um misticismo mecânico... A obra representa apenas a negação da tradição clássica e da arte nacional". ${ }^{19}$

O debate sobre o formalismo chegou à Alemanha Oriental em $1948 \mathrm{com}$ um artigo publicado no Tägliche Rundschan e escrito por Alexander Dymschitz, o principal funcionário do setor da cultura da administração militar soviética. ${ }^{20} \mathrm{Em}$ um esforço de definir o que seria uma arte nacional "aceitável", os funcionários da Alemanha Oriental oficialmente entraram no debate sobre o formalismo durante o terceiro congresso do SED, em 1950. Depois de iniciada a Campanha do Formalismo, só havia duas possibilidades: ou a arte se enraizava no solo nacional ou ela era estrangeira e, portanto, decadente. Em um artigo publicado em novembro de 1951, N. Orlow alegava que todo formalismo era "vazio de conteúdo positivo" e, portanto, prejudicial ao povo da RDA. Segundo Orlow, o povo necessitava de "uma cultura que tornasse claramente compreensível a luta histórica do povo alemão e do mundo inteiro pela abolição da escravidão e da exploração". Ele exigia que "toda influência da decadência ocidental... fosse combatida" ${ }^{21}$

$\mathrm{Na} \mathrm{RDA}$, a acusação de formalismo estava intimamente ligada à acusação de cosmopolitismo, e a luta contra ambos tornou-se parte do nacionalismo comunista da Alemanha Oriental. De acordo com Ernst Hoffmann, membro do Comitê Central do SED, o cosmopolita era "cinicamente desdenhoso" de todas as obrigações morais e deveres nacionais. É alguém que está disposto "a matar os trabalhadores de todos os povos e a transformá-los em objetos abstratos e esquemáticos de exploração, a arrancá-los de suas conexões com seu povo e sua classe, a roubar deles suas características nacionais". ${ }^{22}$ Como observou Jeffrey Herf, o nacionalismo comunista, com seu foco no futuro, também "andava lado a lado com a tarefa de aliviar os alemães do peso de seu difícil passado" (apud Herf, 1997, p.110). Para os intelectuais, isso significava esquecer o passado recente e retornar, de uma forma hagiográfica, aos clássicos da tradição cultural alemã, entre eles Goethe, Bach, Heine e outros.

Inextricavelmente ligado com a tentativa do SED de consolidar seu poder estava o gradual estreitamento de possibilidades na esfera cultural. A cultura precisava promover o estado, servir de instrumento de propaganda para a política do estado. Com o intuito de controlar a cultura de um modo mais completo, e de liderar o ataque contra o formalismo, o partido criou novas instituições, das Amt für Literatur e die Staatliche Kommission für Kunst, em 1951. Qualquer forma de arte que fosse considerada oposta às restrições impostas era considerada formalista e cosmopolita, e ser rotulado de formalista ou cosmopolita significava estar ligado ao Ocidente - acusação especialmente perigosa nesse contexto. ${ }^{23}$

Dessa forma, as acusações contra Lukullus foram graves e Brecht e Dessau ficaram em uma posição precária. Dessau queria recuar após as primeiras reações, mas Brecht era contra ceder tão depressa. O material, dizia ele a Dessau, era especialmente importante naquele momento, quando "as ameaças americanas são tão histéricas". Além disso, dizia Brecht, a "crítica nunca deve ser temida; devemos rebatê-la ou aceitá-la, só isso" (Arbeitsjournal, p.943). Depois de 
ter sido concedida a permissão para uma estréia com uma platéia rigorosamente controlada, realizou-se uma discussão formal sobre a ópera e os problemas gerais da arte formalista. Durante essa discussão, Brecht não recuou. Defendeu não apenas a ópera em si, mas também a necessidade de liberdade artística. Dias depois, Wilhelm Pieck "convidou" Brecht e Dessau para uma "discussão pessoal” em seu apartamento. Também estavam presentes Otto Grotewohl, Paul Wandel, Anton Ackermann e Hans Lauter (Pieck to Brecht, 20 March 1951, BBA, 135/12). Infelizmente, não restou nenhum registro dessa reunião, mas a ópera foi suspensa até que mudanças adequadas pudessem ser feitas. Embora em particular discordasse das exigências e continuasse a defender a si mesmo, a ópera e Dessau, em reuniões oficiais e cartas particulares, Brecht dessa vez curvou-se aos desejos da elite do partido (cf. Willett, 1990, p.500). Ele e Dessau fizeram várias alterações importantes, que o partido aceitou. ${ }^{24}$

As anotações e a correspondência particular de Brecht indicam que ele entendia que o debate sobre o formalismo e o cosmopolitismo era parte do processo de consolidação do poder na nova RDA. O próprio termo "formalismo" estava sendo empregado de uma forma tão vaga que podia significar qualquer coisa e nada ao mesmo tempo. Brecht comentou com Käthe Rülicke, sua assistente e amante, que Orlow e outros nunca haviam nem mesmo oferecido uma definição do termo. Eles diziam apenas que o formalismo devia ser "combatido" (BBA, 1340/45). Sem dúvida, havia razão suficiente para uma oposição ao formalismo, mas a "luta contra o formalismo deve ser dirigida tanto contra a liquidação das formas quanto contra sua predominância". A arte socialista adequada não devia se opor a todas as novas formas, mas apenas "àquelas formas que distorcem a realidade", e deve favorecer os "impulsos que promovem o socialismo" (BBA, 1340/89). A frustração de Brecht se devia, em grande medida, ao que ele considerava ser uma desnecessária intromissão dos burocratas do partido nos assuntos culturais. Como relatou Rülicke, "Brecht não deseja aprender com Ulbricht como poetizar, mas são os políticos que devem aprender dos poetas, que representam a sociedade inteira... Os políticos não podem dizer nada sobre as formas artísticas!" ${ }^{25}$

Brecht, entretanto, acreditava que a RDA ainda estava em uma fase de transição. Como relembrou Peter Huchel (1984, p.375), Brecht "via a RDA como um grande canteiro de obras que ainda precisava de muito trabalho". Um dos problemas era que a RDA ainda não tinha se livrado dos vestígios dos padrões tradicionais de pensamento. "É um grande azar da nossa história", escreveu Brecht em 1951, "que devamos realizar a construção do novo sem ter realizado a demolição do antigo. Provavelmente por esse motivo, olhamos para a construção [do novo] de uma forma que não é dialética. [Assim] não podemos expressar de forma adequada a luta diária contra o antigo que ainda temos de realizar" (GKBA, v.17, p.103).

Em 1953, uma confluência de acontecimentos políticos e culturais ofereceu a Brecht uma condição propícia para a realização de seus objetivos: uma sede permanente para seu teatro e a restauração da autonomia nas artes, para que uma 


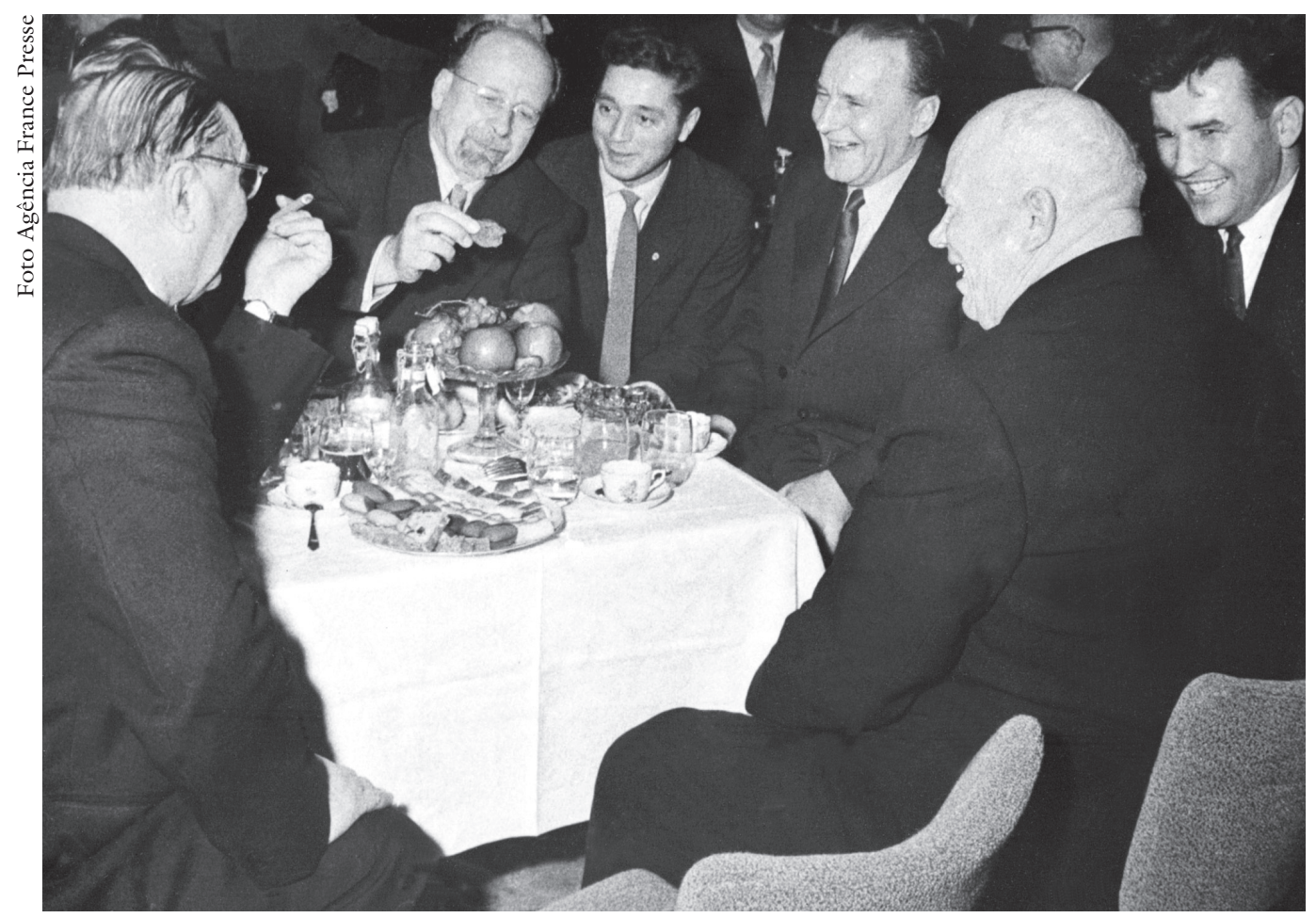

Da esq.: Ferenc Munnich, presidente do Conselho de Estado da Hungria; Walter Ulbricht, primeiro-secretário do Partido Socialista Unificado da Alemanba (SED); Janos Kadar, primeiro-secretário do Partido Comunista Húngaro; Nikita Khrushchev, presidente da União Soviética, durante o 7o Congresso do Partido Comunista da Hungria, em Budapeste, em 1959.

cultura genuinamente socialista pudesse surgir. Começando no verão de 1952, o regime de Ulbricht vinha tentando acelerar a transformação da RDA na direção do socialismo, e esperava-se a adesão da elite cultural. ${ }^{26}$ Não haveria mais nem mesmo uma liberdade artística limitada. Em fevereiro e março de 1953, Hanns Eisler e Brecht foram atacados em virtude de seu tratamento do tema de Fausto. Objeto de discussão tanto na Alemanha Oriental quanto na Ocidental, especialmente após a celebração do bicentenário de Goethe, o tema de Fausto foi diretamente ligado à tentativa de encontrar uma tradição cultural utilizável. A figura de Fausto proporcionou a Brecht, dessa forma, a oportunidade de lidar com dois dos seus temas mais importantes durante o período pós-guerra: a tradição cultural burguesa e o relacionamento entre os intelectuais e a sociedade.

Embora a produção do Urfaust de Goethe realizada pelo Berliner Ensemble não fosse de grande importância, Brecht participou das discussões dramatúrgicas no Berliner Ensemble e as coordenou. Ali, ele expôs seu ponto de vista sobre a figura de Fausto que, como Läuffer, era um símbolo do intelectual tradicional da Alemanha. Não mais um grande herói, o Fausto de Brecht representava a "decadência burguesa" e era um intelectual traidor de seu povo. De acordo com Brecht, Fausto era "um parasita; ele absorve o conteúdo de livros e do conhecimento até ficar farto. Vive do que eles lhe oferecem, mas nunca 
paga". Homens como ele "não produzem nada; apenas tomam dos outros" (BBA, 1340/27).

Ao mesmo tempo, Eisler estava compondo a ópera Johann Faustus. Ele desenvolveu uma concepção própria da figura de Fausto em colaboração com Brecht, que retrabalhou o texto para a ópera $(G K B A$, v.27, p.333). Esses dois trabalhos foram discutidos na Academia das Artes no início de 1953. Como aconteceu com Lukullus, as acusações eram de formalismo, cosmopolitismo e difamação do "herói nacional". Alexander Abusch, importante membro do conselho da Academia das Artes e ele mesmo uma vítima recente do regime de Ulbricht, foi particularmente crítico, assim como Johanna Rudolph, e escreveu que Brecht e Eisler "deveriam ter em mente a situação em que o povo alemão se encontra... Fausto representa o melhor do povo alemão. A defesa dessa grande criação de nossa cultura nacional... deveria ser o desejo de todos os escritores humanistas". ${ }^{27}$

Pelo ano de 1953, qualquer crítica feita à tradição clássica alemã era considerada pela elite do partido um ataque à RDA, que estava tentando forjar uma identidade de "democracia popular" alinhada com desenvolvimentos culturais e políticos progressivos anteriores. Assim, o regime não só censurou Eisler e Brecht, mas também outros intelectuais dissidentes que desviavam da norma, incluindo o editor do Sinn und Form, Peter Huchel. O Sinn und Form, idealizado por Becher, era o porta-voz literário da Academia das Artes (BBA, 795/24). Huchel, que não era membro do partido, sempre mantinha um alto grau de independência e freqüentemente entrava em conflito com o SED. No final de 1952, ele publicou tanto o libreto de Johann Faustus quanto um ensaio crítico sobre Faustus, de autoria de Ernst Fischer. Esse tipo de independência não podia mais ser tolerado. Dessa forma, o partido resolveu derrubar Huchel e fechar o jornal. Na reunião do conselho da Academia realizada em 13 de maio de 1953, foi tomada a decisão de "preparar a extinção do jornal Sinn und Form e a demissão do editor-chefe Peter Huchel" (Hecht, 1997, p.1057). Huchel foi informado em 2 de junho de que estava sendo transferido e, sob enorme pressão, concordou em afastar-se. Furioso, Brecht implorou a Huchel que "protegesse" sua "posição, assim como eu protejo a minha". Em uma declaração que mostra claramente como Brecht entendia bem sua própria instrumentalização, ele apontou que o Sinn und Form, juntamente com o Berliner Ensemble, eram "os melhores cartões de visita da RDA". ${ }^{28}$

Foi também durante esses poucos meses que a ópera de Eisler foi intensamente bombardeada. Girnus, juntamente com os funcionários do setor cultural Heinz Kamnitzer e Hans Rodenberg, foi particularmente crítico. Brecht e Arnold Zweig defenderam a ópera. Depois de suas discussões em reuniões fechadas da Academia, Girnus publicou um artigo no Nenes Dentschland no qual atacava o Johann Faustus de Eisler por seu formalismo. ${ }^{29}$ Abusch também publicou um ensaio em que atacava a ópera por retratar os intelectuais como "traidores" das forças progressivas da história alemã. Enquanto o Fausto de Goethe era "um 
grande herói positivo do drama alemão", e um predecessor direto do realismo socialista, o Faustus de Eisler tinha "traído" suas raízes camponesas (Abusch, 1953, p.179-94).

Eisler, que era membro do partido, enfrentou não só a censura, mas também foi ameaçado de prisão ou exílio. Durante as reuniões de maio e junho da Academia, Brecht defendeu Eisler e, em termos mais genéricos, a necessidade de liberdade artística (Heiser-Duron, s. d.). Ele também partiu pessoalmente para o ataque, criticando a política cultural da RDA. Em fevereiro, ele defendeu Eisler perante Hans Mayer:

Mais uma palavra sobre o "negativismo" que determinadas pessoas... atribuem ao Fausto de "Eisler". Com certeza um desejo justificado de ver heróis (modelos) positivos não deve nos levar a rejeitar o retrato de grandes figuras como Fausto, cuja influência pode ser igualmente positiva no sentido social. A literatura mostra que a tragédia pode desempenhar algumas das funções da comédia, um certo esclarecimento social, quero dizer. (cf. Willett, 1990, p.514)

A ópera de Eisler, alegava Brecht, era "uma obra literária importante por causa de seu grande tema nacional, por causa do nexo conceitual, por causa de sua linguagem, por causa da riqueza de suas idéias". Em uma reunião oficial fechada no dia 27 de maio de 1953, Brecht concordou que a história alemã "não pode e não deve ser representada negativamente", mas, acrescentou ele, Eisler concordava com seus críticos nesse ponto. Na opinião de Brecht, Eisler tinha "feito uma contribuição positiva para o grande problema de Fausto". ${ }^{30}$ Eisler entendia a grande importância do apoio de Brecht naquele momento. Como ele escreveu à esposa em 28 de maio, "Brecht apresentou teses brilhantes acerca e a favor do Faustus". Entretanto, observou ele, elas foram "ineficazes" (Eisler, 1985, p.278). Por fim, a oposição a Eisler ficou forte demais. Em meados de junho, sob pressão pesada, ele partiu de Berlim Oriental para Viena, onde permaneceria até fevereiro de 1954.

Embora o formalismo ainda estivesse em questão, o contexto político era diferente em 1953 do que tinha sido em 1951. Mudanças importantes estavam ocorrendo na liderança do SED durante a primavera e o início do verão de 1953, mudanças que culminaram na insurreição de 16 e 17 de junho. A liderança tinha tentado acelerar a transformação da vida política e social em 1952 com várias reformas. A mais controversa durante 1953 foi a proposta de aumentar as normas de trabalho em 10\%, uma exigência que gerou enorme descontentamento entre os trabalhadores. A tarefa de sancionar as novas normas tornou-se ainda mais difícil quando Moscou informou Ulbricht que desaprovava a política do SED. Beria, chefe da polícia secreta da URSS e aparentemente o herdeiro indiscutível de Stalin, fez ácidas críticas. Moscou também estava passando por rápidas mudanças após a morte de Stalin em março de 1953. A liderança soviética empreendeu um "Novo Curso", que incluía uma medida de descentralização política e um enfoque na produção de bens de consumo. Na Alemanha Oriental, havia 
naturalmente uma grande dose de incerteza política e partidarismo. No início de junho, Ulbricht, Grotewohl e Oel $\beta$ ner foram chamados a Moscou para serem informados sobre a nova política do partido.

Em 9 de junho, o Politburo da Alemanha Oriental fez um comunicado oficial admitindo "alguns erros" e aceitando uma mudança de curso imposta pelos soviéticos. O aumento das normas de trabalho, entretanto, não foi nem sequer mencionado. O comunicado oficial foi publicado no dia 11 de junho no Neues Deutschland. Exasperados diante da manutenção do aumento das normas, os trabalhadores enfrentaram funcionários do partido e instituíram "operações tartaruga" e fizeram protestos a partir de 12 de junho. A tensão continuou a aumentar, e no dia 16 de junho os funcionários do setor da construção marcharam até a sede do sindicato para fazer uma manifestação. Eles exigiam um encontro com Ulbricht e Grotewohl, mas só conseguiram conversar com o ministro da Indústria Pesada Fritz Selbmann e Robert Havemann, presidente do Conselho de Paz da RDA. Os trabalhadores exigiam a retirada das novas normas e, insatisfeitos com a resposta, convocaram uma greve geral. No início da manhã de 17 de junho, os trabalhadores exigiram não só a retirada das normas de trabalho, mas também uma queda nos preços, eleições livres e a renúncia do governo. Essas exigências não obtiveram nenhuma ou quase nenhuma resposta das autoridades, e causaram mais frustração e, por fim, violência (Ostermann, 2001, p.160ss). Ao anoitecer de 17 de junho, tanques e tropas soviéticas haviam tomado a cidade e restaurado a ordem.

Embora algumas mudanças políticas tenham sido implementadas na esteira dessa insurreição, entre elas a anulação do aumento das normas de trabalho, Ulbricht, que se viu em risco de perder poder, respondeu com sanções severas. A liderança do partido prendeu mais de seis mil pessoas envolvidas na insurreição, incluindo não apenas grevistas e líderes do movimento, mas também milhares de membros do SED que não concordavam com a política do partido. Além disso, houve um expurgo de membros das facções dissidentes da liderança do SED, incluindo o ministro da Defesa Wilhelm Zaisser, o ministro da Justiça Max Fechner e Rudolf Herrnstadt, editor do Neues Deutschland.

Brecht, cuja reação às sanções governamentais tem sido alvo de acalorada controvérsia, entendeu que aquele era um momento crucial e aproveitou a oportunidade para iniciar algumas mudanças importantes na política cultural. Käthe Rülicke, que esteve ao lado de Brecht quase constantemente durante essa crise, registrou que ele ficou "profundamente perturbado" e até "deprimido" porque "logo na Alemanha, que já havia experimentado o fascismo, os trabalhadores (e tratava-se de trabalhadores) foram se posicionar contra o primeiro governo de trabalhadores". Brecht era solidário com os trabalhadores, mas acreditava que "tudo deve ser feito para evitar outra catástrofe" (BBA, 2164/05-06). Em público, Brecht nada dizia sobre a insurreição, mas escreveu cartas de apoio tanto para Ulbricht e Grotewohl como para o funcionário soviético Vladimir Semyonov. Para Ulbricht ele escreveu: 
A história vai prestar suas homenagens à impaciência revolucionária do Partido da União Socialista da Alemanha. A grande discussão [diálogo] com as massas sobre a velocidade da construção socialista vai conduzir a uma visão e a uma proteção das realizações socialistas. Neste momento, devo expressar minha fidelidade ao Partido da União Socialista da Alemanha.

A penúltima frase continha a sugestão de Brecht para que houvesse uma discussão dos erros cometidos pela liderança do partido, em vez de mais opressão, e indica até que ponto Brecht continuaria protestando em particular contra a opressão, mesmo tendo de disfarçar seu protesto em meio a garantias de lealdade. Tendo em vista que Brecht era extremamente cauteloso em termos pessoais, a frase para Ulbricht é notável. Para Semyonov, ele declarou sua "inabalável amizade pela União Soviética” (Brecht, 1981, p.1793, 1795; BBA, 7/07).

Embora, em particular, estivesse disposto a dar apoio ao regime, Brecht estava menos disposto a fazer isso publicamente. No dia 17 de junho, em uma reunião especial do conselho da Academia das Artes, Abusch e Rudolf Engel sugeriram que a Academia publicasse um "manifesto" que servisse como uma "declaração de apoio" ao regime. Brecht recusou a idéia. Aquilo era impossível, disse ele, porque os presentes não podiam falar por toda a Academia. Além do mais, como o regime não tinha tomado uma posição oficial, era impossível para a academia "responder a uma resposta inexistente". Brecht argumentou que "uma simples declaração de apoio naquela situação seria errada". Em vez disso, deveria ser iniciado um projeto mais significativo de longo prazo, um projeto que envolvesse "a participação ativa da Academia e a reforma da vida cultural" (DAK, 18/35-6).

Alguns dias depois, em 21 de junho, apenas a última linha da carta de Brecht para Ulbricht foi publicada no Neues Deutschland. Naturalmente desgostoso por a carta ter sido publicada sem a sua autorização, ele ficou furioso porque sua sugestão de um debate sobre os erros tinha sido omitida. Ele entendia que isso poderia manchar sua reputação no exterior, especialmente na Alemanha Ocidental, e ele não podia perder seu valor de mercadoria naquele momento. Por intermédio de Peter Suhrkamp, ele ficou sabendo que, depois de sua "declaração de lealdade", os teatros do lado ocidental estavam se recusando a encenar suas peças. ${ }^{31}$ Ele protestou para Gustav Just, editor do Sonntag, dizendo que aquele ato tinha sido "indelicado, pois ninguém havia discutido com ele a publicação naquele formato". Além disso, seria "prejudicial" para sua obra, que se destinava a toda a nação alemã. ${ }^{32}$

Quase imediatamente, Brecht começou a tentar reparar o dano e oferecer um quadro mais claro de sua posição. Em 23 de junho, ele publicou uma declaração, juntamente com Slatan Dudow, Wolfgang Langhoff e outros, na qual expressava sua esperança

de que os trabalhadores, que fizeram uma demonstração motivados por uma insatisfação justificada, não fossem colocados no mesmo nível de agentes infiltrados que trabalhavam para insuflar a desordem, para que a urgente e necessá- 
ria discussão sobre os erros cometidos de todos os lados não se torne impossível antes mesmo de começar. ${ }^{33}$

Enquanto isso, nos bastidores, em reuniões da Academia Alemã das Artes e do Berliner Ensemble, ele começou a fazer um movimento pela reforma da política cultural. Embora pudesse não concordar com as ações dos trabalhadores, certamente ele conseguia entender as queixas deles. A questão era criar uma sociedade sem classes. Portanto, era necessário reconhecer o abismo entre os fatos da vida como ela realmente era e o objetivo desejado. Esse abismo não podia simplesmente ser negado ou ignorado sem que se abandonassem os princípios do próprio marxismo. Durante as semanas que se seguiram a 17 de junho, Brecht participou de várias discussões sobre a situação daquele momento e a necessidade de mudar a política cultural. Em uma reunião do Berliner Ensemble que ocorreu nos dias 24 e 25 de junho, ele argumentou que "nos estágios iniciais tratava-se de uma questão grave e chocante que até mesmo os trabalhadores estivessem fazendo demonstrações aqui". Eles tinham "todas as justificativas” para proceder assim, mas elementos nazistas também estavam em ação. Na opinião de Brecht, era "um dos principais erros do SED e do regime que esses nazistas... não tenham sido destruídos". Além disso, "era um erro... que fosse tabu... falar da era nazista". Apenas a "magnífica cultura do povo alemão, apenas o que era positivo" era mencionado. Esse era um dos principais pontos da "discussão supérflua sobre o texto de Faustus". Do ponto de vista de Brecht, “toda a gangue nazista ainda está presente; ela não governa mais, mas está ainda muito viva espiritualmente". Mas ninguém deveria falar sobre isso; esse assunto deveria ser "silenciado" (BBA, 1447/102). Fazia sentido dizer, portanto, que grande parte da crise tinha sido precipitada pela política cultural do SED. "A política cultural", escreveu ele, "teve resultados desastrosos" (BBA, 1447/119).

Se Brecht reconhecia que o regime tinha cometido erros, ele também acreditava que os excessos de 16 e 17 de junho eram em parte resultado da provocação de elementos fascistas dentro da Alemanha Oriental, bem como de agentes da parte ocidental infiltrados. Como escreveu ele a Suhrkamp:

O Partido da União Socialista cometeu erros que foram extremamente graves... e que despertaram a revolta de alguns trabalhadores... Mas eu respeito muitas de suas realizações históricas, e me senti alinhado com o partido - não por causa de seus erros, mas em virtude de suas boas qualidades - quando ele foi atacado por uma corja fascista e belicosa... Você pergunta sobre minha atitude em relação aos eventos de 16 e 17 de junho... Será que fui indiferente, para não dizer hostil, a uma insurreição popular, será que fiquei contra a liberdade quando, em 17 de junho, em uma carta ao Partido da União Socialista, cuja última sentença foi publicada, eu expressei minha prontidão em contribuir de minha própria forma (na forma artística) para o debate absolutamente indispensável entre os trabalhadores e o governo? Há três décadas tenho tentado em meus textos defender a causa dos trabalhadores. Mas na noite de 16 e na manhã de 17 de junho eu vi o movimento de manifestação dos trabalhadores degenerar em algo muito distan- 
te de uma tentativa de conquistar a liberdade. Os trabalhadores tinham motivo para se sentir amargurados. As medidas infelizes e pouco inteligentes tomadas pelo governo em uma tentativa de precipitar o desenvolvimento da indústria pesada na RDA enfureceram igualmente camponeses, artesãos, comerciantes, trabalhadores e intelectuais... Essas medidas... levaram os trabalhadores às ruas e os fizeram esquecer as indiscutivelmente grandes vantagens que a expulsão dos junkers, a socialização da indústria de guerra de Hitler, a produção planejada e o esmagamento do monopólio burguês da educação tinham trazido. Entretanto, já nas primeiras horas do dia 17 as ruas exibiam uma mistura grotesca de trabalhadores não somente com todos os tipos de jovens desclassificados, que se infiltravam pelo Portão de Brandemburgo, derramavam-se na Potsdamer Platz e formavam colunas através da Ponte de Varsóvia, mas também com figuras grosseiras e embrutecidas da era nazista, o produto local... [elementos] que estavam aqui o tempo todo. Os slogans mudaram depressa. "Abaixo o governo" foi seguido de "Todos para a forca"; a ralé dominou a cena... Por várias horas, até que as forças de ocupação entraram, Berlim esteve à beira de uma terceira guerra mundial. (cf. Willett, 1990, p.517-8, itálicos no original)

Embora Brecht tenha, sem dúvida, exagerado o papel dos agentes ocidentais infiltrados e a gravidade da situação, não se tratava apenas de mera encenação. Brecht acreditava verdadeiramente que a nova sociedade socialista que esperava construir tinha sido colocada em risco por elementos externos $e$ internos. A crise devia-se em parte a erros cometidos pela liderança do SED, o que incluía seu fracasso em lidar de forma adequada com seu passado recente, em eliminar todos os vestígios do nazismo, mas também resultava de elementos fascistas da Alemanha. Não fica claro se Brecht chegou a reconhecer em que medida sua posição a esse respeito era influenciada pela propaganda política da União Soviética e da Alemanha Oriental. Entretanto, é evidente que sua decisão de apoiar o regime foi motivada, em parte, por seu desejo de melhorar a nova sociedade socialista que estava sendo construída na RDA - o que incluía expulsar seus elementos fascistas. Também era crucial, entretanto, o retorno da autonomia nas artes. Brecht não argumentava em favor de uma liberdade artística absoluta. Como ele ressaltou, "não se pode criar uma república de artistas, onde cada um possa produzir o que bem entender. Não especialmente em uma Alemanha que sofreu duas décadas de domínio nazista” (BBA, 1447/121). Não obstante, como ele escreveu em seu poema "Não o que foi desejado", era preciso "libertar a expressão artística sob o controle dos burocratas tacanhos". ${ }^{34}$

Motivações profissionais e pessoais também influíram no pensamento de Brecht nesse momento. Essas preocupações e interesses diferentes sempre estiveram presentes no Brecht pós-guerra, mas em configurações e proporções que se alteravam. No momento em questão, seus interesses pessoais, profissionais e ideológicos convergiram. Ele reconheceu que, finalmente, poderia conseguir uma sede permanente para sua companhia teatral, mas também sabia que o teatro seria de pouco valor, ao menos que ele tivesse algum controle artístico. Dessa forma, Brecht começou a usar várias táticas para forçar a mudança e, ao 
mesmo tempo, obter o Theater am Schiffbauerdamm. Ele várias vezes enfatizou seu prestígio internacional e sua reputação doméstica. Também se valeu de seus relacionamentos com intelectuais importantes e funcionários do partido - e talvez esse tenha sido o aspecto mais importante. Como apontou Meredith Heiser-Duron (s. d., p.52), ele "trabalhou de forma auspiciosa com uma improvável combinação de quatro pessoas", a saber: "Johannes Becher, Otto Grotewohl, Paul Wandel e Wilhelm Girnus". Nos bastidores, ele fez uma pressão ainda maior por mudanças nas políticas culturais, e convenceu essas e outras personalidades culturais a apoiar seus planos, embora se recusasse, com poucas exceções, a "manifestar publicamente" suas críticas sobre as políticas culturais.

Em reuniões fechadas, ele pressionava a Academia das Artes para que lançasse sugestões de mudanças nas políticas culturais. Em 12 de julho, a Academia, depois de enfrentar muita resistência por parte de Grotewohl e de outros, conseguiu publicar uma lista de dez "sugestões", a maioria das quais se destinava a devolver um grau de autonomia aos artistas. Entre as sugestões mais importantes, estava a de que os artistas ficassem responsáveis pela produção e publicação de suas obras. Além disso, era necessário que a Academia tivesse voz na escolha dos "mais importantes indivíduos responsáveis pelas questões artísticas". Finalmente, a Academia declarou que "os eventos de 17 de junho" tinham provado que "a luta contra o fascismo em todas as suas formas deve ser empreendida de novo e com renovado vigor - até mesmo pelos artistas". ${ }^{35}$ Todas essas sugestões trazem, sem dúvida, a marca de Brecht, e um exame cuidadoso dos protocolos sugere que ele foi muito influente em seu desenvolvimento. Ninguém na Academia possuía a combinação de dotes intelectuais e políticos que Brecht apresentava. Por esse motivo, ele foi seu líder natural nesse momento.

Brecht também continuou a lutar por sua causa, o Theater am Schiffbauerdamm. Repetidas vezes enfatizou diante do partido a sua importância como dramaturgo internacionalmente reconhecido. Em 15 de junho, mesmo antes da insurreição, ele tinha escrito a Grotewohl:

Você provavelmente ouviu falar dos boatos mais estranhos que têm circulado na Alemanha Ocidental sobre atritos entre mim e o governo da República Democrática Alemã. Se o Berliner Ensemble, que é conhecido muito além das fronteiras da Alemanha, assumisse o Theater am Schiffbauerdamm, minha solidariedade com nossa república ficaria evidente para todos. (cf. Willett, 1990, p.515)

Embora Brecht em geral se recusasse a criticar o regime em público, nessa época ele publicou dois poemas que o criticavam. Seu duplo objetivo era destruir Das Amt für Literatur e Die staaliche Kommision für Kunst e substituir essas duas organizações por um ministério da cultura, liderado por seu amigo Becher. Em uma conversa particular com Wolfgang Harich, influente filósofo e jornalista - e também um de seus mais próximos aliados durante esse período -, Brecht revelou muito acerca de seus planos. Harich sugeria que eles seguissem o exemplo de Tito na Iugoslávia. Brecht respondeu: 
Você está louco. Você vai acabar na forca... De qualquer forma, eu não quero saber de nada sobre a briga entre os partidários de Tito e os stalinistas... Minhas peças deveriam ser representadas em Moscou e em Belgrado. Por esse motivo, não vou me juntar a um partido. Sou a favor do comunismo em geral, mas não a favor dessas formas individuais: Stalin-Tito, para mim é tudo a mesma coisa... Queremos fazer algo real. Queremos nos livrar dos burocratas da política cultural. Você escreve um artigo contra aquele determinado artigo e eu acrescento alguns poemas e depois nós colocamos Johannes R. Becher como ministro da cultura. ${ }^{36}$

O artigo de Harich, que foi publicado em 14 de julho, criticava não apenas a comissão de artes em termos gerais, mas também determinados indivíduos, incluindo Girnus e Helmut Holtzhauer, um dos principais membros da Kunstkommission. Em 15 de julho Brecht publicou Das Amt für Literatur, em que ele criticava diretamente esse órgão de controle por publicar apenas obras “com idéias com as quais o Departamento de Literatura está familiarizado através dos jornais". ${ }^{37}$ Em Erros não identificáveis da Comissão de Artes, ele criticou duramente a Comissão. Nesse poema, ele afirmou que

os mais graduados membros da Comissão de Artes/Pagaram seu tributo ao nobre costume de/ acusar-se de certos erros, e/Murmuraram que eles também acusavam a si mesmos de certos erros. Entretanto/Quando interrogados sobre quais erros estavam falando eles julgaram impossível/ Lembrar qualquer erro específico. Tudo o que/ a Academia mantinha contra eles/Não tinha sido precisamente erro nenhum, pois a Comissão de Artes/nada tinha suprimido, mas apenas não o tinha promovido./ Apesar das mais zelosas ruminações/ Eles não conseguiam lembrar-se de nenhum erro específico, entretanto/ Eles insistiam com veemência que tinham/Cometido erros - como é de costume. (Brecht, Poems, p.436)

Em particular, Brecht continuava criticando vários funcionários, incluindo Grotewohl e o ministro da Educação Pública, Paul Wandel. Para Wandel ele escreveu que "a Comissão de Artes deve ser dissolvida de forma ampla e completa". A Comissão tinha transformado todos os artistas em seus inimigos, e também "conseguido transformar os princípios mais progressistas em algo próximo do descrédito". Brecht apontava que as tarefas administrativas da Comissão podiam ser desempenhadas de melhor forma pelo "Ministério da Cultura, e a Área Cultural do Partido da Unidade Socialista", que "poderiam exercer uma influência de muito maior autoridade nas questões artísticas... $\mathrm{O}$ que necessitamos agora é simplesmente deixar os artistas livres para que eles possam produzir" (Brecht, 1981, p.520-1). Para Girnus, em uma reunião particular em agosto, ele mais uma vez enfatizou sua reputação internacional e também a do Berliner Ensemble. Nessa mesma reunião, Brecht deu a Girnus um artigo para que fosse publicado no Neues Deutschland, no qual ele reafirmava o direito da Academia de "exercer a crítica". Ele apontava que a própria Academia tinha cometido erros e, portanto, tinha minado a confiança de muitos artistas no novo 
estado, sem a qual "nenhum estado novo pode ser construído". Um dos mais significativos erros na política cultural, afirmava ele, era que a RDA tinha virado as costas "cedo demais" para o "passado imediato" a fim de abraçar seu futuro; entretanto, o futuro dependia da "libertação do passado". Para que a RDA realizasse totalmente seu potencial, criasse uma "produtividade geral de toda a nação", a arte teria de "criar um novo impulso". ${ }^{38}$

Em poucos - mas decisivos - meses, Brecht conseguiu atingir a maioria de seus objetivos. Em virtude do desequilíbrio após 17 de junho, Brecht, juntamente com Becher, convenceu Abusch e outros membros da elite do partido a permitir que Huchel continuasse como editor do Sinn und Form, a escolher a dedo os membros de uma comissão que o aconselharia em relação ao conteúdo do jornal. ${ }^{39}$ Brecht abrandou o ataque a Eisler e o ajudou a escrever do próprio punho um pedido de desculpas ao Comitê Central do SED. Eisler retornou à RDA e reassumiu sua carreira, embora bastante moderado em razão desse evento. Brecht também foi útil na substituição de Das Amt für Literatur e de Die staatliche Kommission fur Künst - as duas instituições criadas para coordenar uma campanha antiformalista - por um novo Ministério da Cultura, liderado por seu amigo e aliado Becher. Esse Ministério da Cultura foi estabelecido no início de 1954, e pouco depois disso Brecht foi indicado para um conselho cuja responsabilidade era "orientar" Becher em relação à política cultural. Esse cargo era ideal para Brecht, que sempre preferia trabalhar nos bastidores ${ }^{40} \mathrm{Como}$ resultado disso, ele conseguiu, em curto espaço de tempo, influir na política cultural - mantendo aliás alguma liberdade artística - de uma forma direta. Finalmente, Brecht conseguiu uma sede permanente para sua companhia teatral, o Schiffbauerdamm, em 1954.

Apesar dessas conquistas, Brecht tem sido criticado por sua recusa a apoiar as ações dos trabalhadores. A imagem que surgiu de Brecht durante esse período crucial é marcada pela covardia e por uma ética que promovia interesses pessoais. John Fuegi argumentou que Brecht foi exposto como um "fiel comparsa dos carrascos" e que "sua posição independente, a plataforma de 'oposição interior', de repente revelou-se como uma ilusão grotesca”. Ronald Hayman (1983, p.370) também observa que Brecht apressou-se em "expressar um apoio cego aos dogmas da ortodoxia". Essas críticas merecem consideração, mas Fuegi e Hayman não levaram em conta a mescla de idealismo e oportunismo que influenciava o pensamento de Brecht nesse momento. Suas ações em 1953 basearam-se em várias considerações aparentemente contraditórias. Interesse próprio, oportunismo e uma crença idealista de que a RDA representava a melhor oportunidade para o futuro da Alemanha foram elementos que desempenharam papéis complexos e inter-relacionados. Brecht não achava que a crise era o fim da linha. Ele a considerava um "Blütezeit", um tempo de florescimento. Não conseguia avaliar "os terríveis acontecimentos de 17 de junho como simplesmente negativos" (GKBA, v.27, 346f.; ver também Brecht, Arbeitsjournal, 520). Freqüentemente, Brecht parecia acreditar que a mudança só podia acontecer por meio 
de uma crise. É possível observar isso, por exemplo, no seu entendimento da crítica artística: "Quando critico uma obra... eu a coloco em crise, ou seja, eu a critico. A obra tem de provar, na pior das circunstâncias, que ela funciona como obra de arte" (BBA, 1340/61). A nova RDA era para Brecht como uma obra de arte. Os acontecimentos em torno de 17 de junho a tinham colocado em crise, tinham provado que ela não estava funcionando de forma adequada e, por isso, precisava ser melhorada (BBA, 2164/24).

Fuegi, Hayman e outros também perderam de vista o contexto da época. Eles supuseram que a crítica pública ao programa do partido era uma opção viável em 1953 e que fazer críticas teria provocado mudanças. Entretanto, a evidência mostra claramente que aqueles que discordaram publicamente do programa do partido sofreram severas punições. Brecht entendia as realidades políticas e embora estivesse comprometido com alguns objetivos de longo prazo, teve de improvisar e muitas vezes fazer acordos à medida que avançava. Ele sabia, por exemplo, que não demonstrar apoio ao regime o teria privado de toda influência como um agente cultural e provavelmente teria anulado suas chances de conseguir o Theater am Schiffbauerdamm. Brecht também entendia que uma sede permanente para sua companhia teatral era importantíssima, mas não teria significado nada se ele não tivesse o controle da produção artística. A maneira de realizar uma mudança política e obter uma sede permanente para sua companhia foi, assim, apoiar o regime em público e trabalhar nos bastidores.

Isso não significou que Brecht não se sentisse em conflito em relação a seus atos. Na verdade, existe um número significativo de evidências anedóticas e literárias - as Bukow Elegies e Turandot - de que Brecht sabia que não tinha mantido uma distância crítica adequada em relação ao regime. Ele escreveu os poemas e a peça, nenhum dos quais foi publicado durante sua vida, enquanto refletia sobre os acontecimentos de 17 de junho. Em "Trocando pneu", ele escreve: "Estou sentado à beira da estrada / O motorista troca o pneu. / Eu não gosto do lugar de onde vim. / Eu não gosto do lugar para onde vou. / Por que impacientemente o observo trocando o pneu?". Em "Grandes tempos, desperdiçados", ele demonstra seu desapontamento com o resultado daqueles dias de junho: "Eu sabia que cidades estavam sendo construídas / Não estive em nenhuma delas. / Questão de estatística, pensei eu / Não de história. // Para que servem cidades, construídas / Sem a sabedoria do povo?". Talvez a passagem mais sugestiva sejam as últimas linhas de "Terrível manhã": "A noite passada, num sonho, vi dedos me apontando / Como se eu fosse um leproso. / Os dedos estavam gastos pelo trabalho e / Eles estavam quebrados. // Vocês não sabem! Eu soltei um grito agudo / Golpeado pela consciência" (Brecht, Poems, p.439-40).

A última peça de Brecht, Turandot, também esclarece sua posição em 1953. Essa peça não despertou muita curiosidade entre os historiadores, mas é crucial tanto por trazer uma forma final à crítica feita por Brecht aos intelectuais, crítica essa iniciada na década de 1930, como também por ilustrar que Brecht 
reconhecia a opressão na RDA e também o seu papel nessa opressão. No início de Turandot, não há como conseguir algodão na China porque o imperador e seu irmão, Jau Jel, detêm um monopólio. Eles estão esperando que os preços subam, para que possam obter mais lucros. Os fabricantes de roupas (Kleidermacher) e as pessoas que não têm roupas (Kleiderlosen) começam a se unir em protesto. Kai Ho, um ex-Tui que é a encarnação do comunismo, lidera uma insurreição. Jau Jel convoca os Tuis para inventar elaboradas desculpas para a escassez de algodão. Em essência, as maiores cabeças do reino estão engajadas em uma competição de mentiras. O "maior enganador" vai salvar o regime e receber a filha do imperador, Turandot, em casamento. Nenhum dos diferentes competidores, que variam de Ka Müh, um personagem que se assemelha a Camus, a Munka Du, que representa Adorno, consegue oferecer explicações viáveis, e todos são executados. Gogher Gogh, uma figura semelhante a Hitler que quer tornar-se Tui mas não passou no exame de admissão, queima metade do estoque de algodão imperial debaixo do nariz dos Tuis remanescentes, para que o restante possa ser vendido em um mercado em alta. Em seguida, ele usa a força bruta para eliminar os Tuis e se casar com Turandot. Mas antes de conseguir forçá-la, os adeptos de Kai Ho intervêm (Brecht, 1968b).

Em um nível, a peça é uma crítica à tradição mandarínica de liderança intelectual na Alemanha. Gogher Gogh é o monstro armado que saiu da cabeça dos Tuis, a verdade das mentiras deles. Em outro nível, entretanto, Brecht estava também ressaltando que os intelectuais de uma sociedade capitalista - e a RDA, embora não fosse capitalista, também não era totalmente socialista - só podem vender suas opiniões. Ele também estava criticando a manutenção de um tipo de liderança intelectual na RDA e sugerindo que as conseqüências haviam sido desastrosas. A fim de criar a Bündnispolitik, foram privilegiados os intelectuais burgueses, como ele. Em alguma medida, isso tinha sido necessário, mas também teve conseqüências desastrosas. Dessa forma, Turandot foi uma crítica da situação na Alemanha Oriental e uma autocrítica. Brecht com certeza reconhecia que ele, também, tinha se tornado um Tui; que ele, também, tinha acobertado as ações do regime de Ulbricht.

As únicas figuras positivas na peça são Kai Ho, representando um intelectual útil e engajado que, por esse motivo, é excluído dos Tuis (Tellektuellen), e o velho camponês Sen, personificação do pensamento prático de Kai Ho. Sen observa que:

a injustiça reina em nossa terra, e na escola dos Tuis só se aprende porque deve ser assim. É verdade que pontes de pedra são construídas sobre os rios mais largos, mas elas levam os poderosos à indolência, e os pobres vagam sobre elas na condição de escravos. É verdade que existe um remédio, mas por meio dele as pessoas se curam para cometer injustiças, e os outros para serem escravizados. As pessoas compram opiniões como se compra peixe; dessa forma, o pensamento fica desacreditado. 


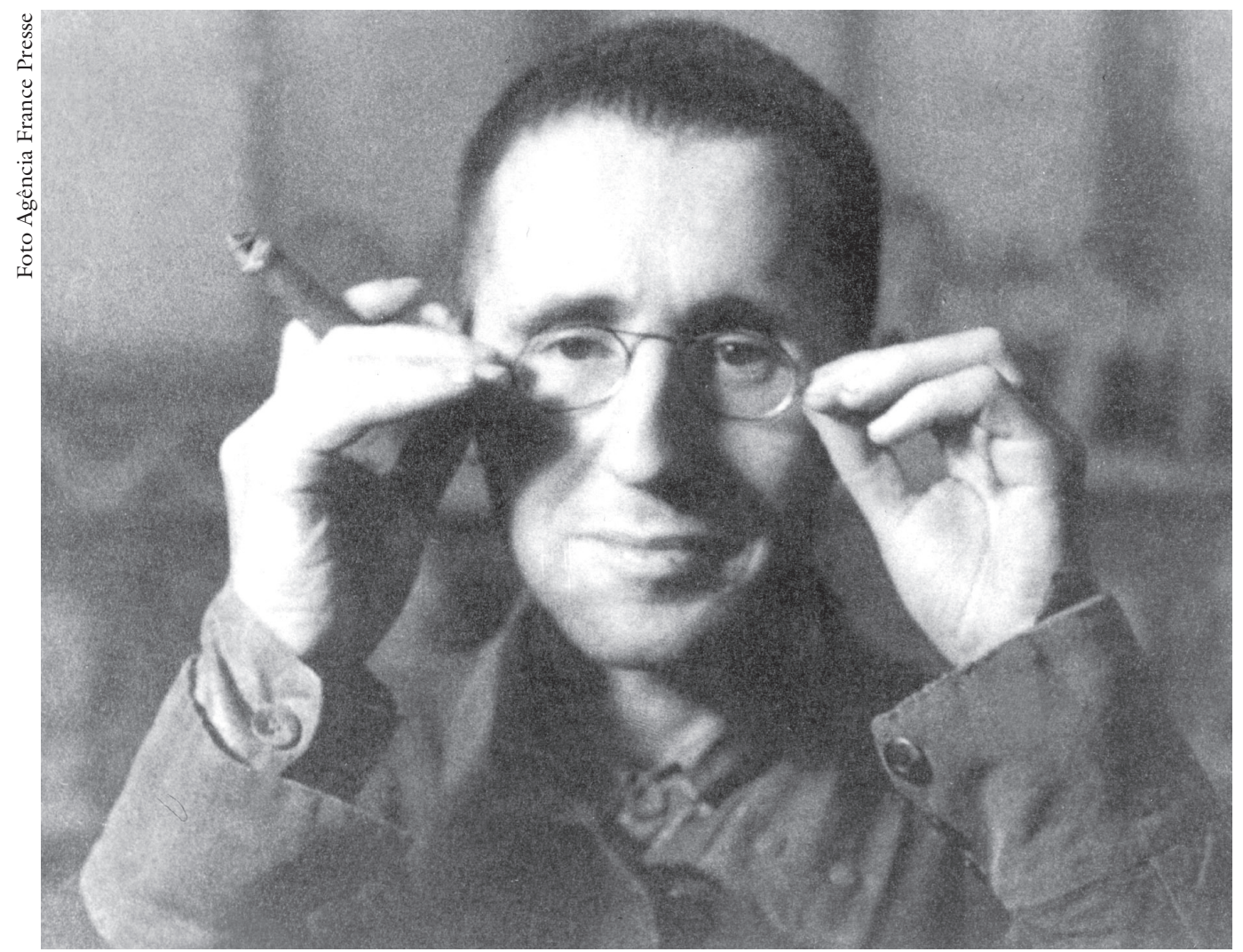

B. Brecht, poeta e dramaturgo, teve suas obras traduzidas e peças teatrais montadas no Brasil.

O intelectual engajado deve, como Sen, mostrar a realidade como ela é. Sem dúvida, Brecht gostaria de se ver desempenhando esse papel, mas ele também sabia que tinha feito acordos para atingir seus objetivos.

Se Brecht não pode ser visto inevitavelmente como um vilão durante esse período, ele também não pode ser propriamente chamado de herói, como Werner Mittenzwei tende a caracterizá-lo. Brecht tinha escolhas e fez acordos. Ele não precisava escrever cartas de apoio aos dirigentes da Alemanha Oriental e da União Soviética. Ele poderia ter defendido os trabalhadores de uma forma mais pública. Poderia muito bem ter escolhido deixar a RDA e trabalhar para o socialismo em outro contexto. Mas, para uma pessoa como ele, a idéia de mudar de lado naquele exato momento parecia quase impensável. Porque exatamente naquele momento o governo da Alemanha Ocidental estava reabilitando antigos nazistas em uma dimensão alarmante, fazendo a RDA parecer, em contraste com isso, muito semelhante ao estado antifascista que sua interesseira religião estatal proclamava ser. Brecht permaneceu em Berlim Oriental porque estava comprometido com a RDA e pensava que poderia realizar alguma coisa por lá, apesar de um aparelho de estado que era stalinista e muitas vezes hostil a suas idéias sobre a arte política. Ele concordava em termos gerais com as políticas da União Soviética e da Alemanha Oriental, e fazia concessões que, segundo acreditava, eram justificadas pela necessidade de combater a permanente influência do fascismo. 
Assim, ele dedicou seus talentos e energia à criação de uma Alemanha verdadeiramente socialista que ele confiava ao futuro, mesmo conhecendo, melhor que a maioria das pessoas, os problemas que a Alemanha Oriental enfrentava naquele momento.

De acordo com Rülicke, ele genuinamente desejava "transformar o socialismo numa realidade". Ele sonhava com uma "nova cidade", com um "novo povo", com o "melhor teatro" e os "melhores políticos", onde se pudesse construir o socialismo. Após 17 de junho, Brecht esperava, e muitas vezes ainda acreditava, que seu sonho "seria de fato realizado" (BBA, 2164/24-25). Por fim, isso o levou a colocar seu nome e seus talentos a serviço de um estado político tacanho e opressor. Se Brecht tivesse vivido após 1956 e até o final da década de 1950, ele também poderia ter ficado tão desencantado - e privado de seus direitos civis - quanto outros antifascistas que retornaram do exílio para a RDA e mais tarde deixaram o país, como Ernst Bloch e Becher. Mas em 1953 Brecht interpretou a situação de forma diferente, e um exame cuidadoso das evidências demonstra que isso pode ser interpretado não apenas como oportunismo da parte dele, embora tenha claramente sido um erro de cálculo..

Críticos como David Pike, Peter Davies e Stephen Parker relegaram Brecht à irrelevância, afirmando que, apesar das mudanças por ele obtidas em 1953, não teve uma influência duradoura na RDA (Pike, 1993; Davies \& Parker, 1998, p.181). Quando se considera apenas a política cultural, essa acusação tem alguma validade. Na esteira da Revolução Húngara, logo após a morte de Brecht, a maioria dos intelectuais dissidentes foi presa, muitas vezes por longos períodos, e toda a autonomia nas artes desapareceu. Mas a incapacidade de Brecht para obter uma mudança duradoura na política cultural não foi necessariamente $o$ resultado da atitude assumida por ele em 1953. Por alguns poucos anos, ele conseguiu reconquistar em certa medida a autonomia nas artes, um feito notável naquele contexto. Além disso, ele representava um tipo de intelectual que muitos futuros intelectuais da Alemanha Oriental desejaram ser: comprometido com a liberdade artística, crítico, disposto a correr riscos, mas não a colocar em perigo sua posição (Rechtien, 1998, p.196ss).

Contemporâneos afirmaram que a própria instrumentalização de Brecht na década de 1950 foi uma compensação bem-vinda e até mesmo indispensável para o clima sufocante da RDA em relação à projetada cultura socialista da nação alemã. $\mathrm{O}$ valor de mercadoria de Brecht perdeu seu poder ao longo do tempo, mas sua crítica dos intelectuais em relação à noção de "tuísmo" envolve um modelo do intelectual público em que a auto-imagem do artista como uma pessoa social e politicamente engajada correspondia às expectativas do público. Partidário sem ser membro de um partido, independente das instituições oficiais e mesmo assim experiente na sobrevivência dentro das instituições, preparado para correr riscos e realizar experimentos não convencionais - foi assim que Brecht acomodou um mundo que ele concebia como mutável e introduziu algumas estratégias poéticas e políticas para dar forma à sua concepção. 
1 Quero agradecer ao National Endowment for the Arts a oportunidade de participar em um seminário sobre Bertolt Brecht em 1998. Agradeço também a Siegfried Mews, Marc Silberman, Meredith Heiser-Duron e David Rouse seu auxílio e aconselhamento. O Academic Enhancement Committee e o Faculty Development Committee da UVA-Wise generosamente apoiaram uma última viagem de pesquisa a Berlim.

2 Ver também o tratamento favorável dado a Brecht em Jens-Fietje Dwars (1998, p.577ss).

3 Ver Bertolt Brecht to Jean Renoir, em John Willett (1990, p.249).

4 Ver Bertolt Brecht, Grosse kommentierte Berliner und Frankfurter Ausgabe, 1955, v.25, p.9 (daqui para a frente citado como $G K B A$ ).

5 Mais tarde, Brecht escreveu poemas sobre esses dois amigos. Ver o poema "Ist das Volk unfehlbar?" (1939) (GKBA, v.14, p.435).

6 Ele também havia criticado Stalin violentamente em seu poema "O agricultor a seus bois", mesmo tendo reconhecido os "imensos méritos" de Stalin (Benjamin, Reflections, p.218-19, itálico no original).

7 A discussão mais clara e completa sobre o complicado relacionamento entre Brecht e Lukács está em Lunn (1982, p.75-128); ver também Pike (1985).

8 Os personagens de As medidas tomadas, por exemplo, representavam pouco mais do que "funções abstratas na luta de classes". "A partir dessa perspectiva de mundo, é impossível verdadeiramente reconhecer e descrever as forças determinantes" (Lukács, 1981, p.70-1); ver também Lukács (1969, v.2, p.166-77).

9 Ver Brecht (1964, p.109-11); ver também "Weite und Vielfalt der realistischen Schreibweise" e "Praktisches zur Expressionismusdebatte" (GKBA, v.22, p.424-32, 41922); Brecht (1973, p.12-4, 28-9).

10 "A era de ouro dos Tuis (Tellekt-uell-in) é a República liberal; entretanto, o Tuísmo atingiu seu ápice durante o Terceiro Reich. O idealismo, no seu nível mais abjeto, celebra seu maior triunfo." Foi durante esse tempo que "o povo" transformou-se em vítima dos "Tuis mais corruptos" (Brecht, 1968c, p.360)

11 Ver "Schwierige Lage der deutschen Intellektuellen", "Wozu braucht das Proletariat die Intellektuellen?" (Brecht, 1968a, p.86-90, 90-1).

12 Brecht foi chamado para responder à acusação de comunismo. Embora não fosse membro do Partido Comunista - e tenha dito isso na audiência com membros do Comitê -, ele tinha evidentes simpatias comunistas, além de ter escrito várias peças marxistas. Na audiência ele foi interrogado sobre Mãe e As medidas tomadas, e lhe perguntaram sobre seus escritos terem ou não sido influenciados por Marx e Lenin. Brecht respondeu de forma evasiva e foi dispensado, com os agradecimentos do comitê. O FBI, entretanto, não ficou satisfeito e pretendia convocar Brecht posteriormente. Antes que pudessem fazer isso, Brecht deixou os Estados Unidos em direção à Suíça, onde viveu até voltar para Berlim Oriental (Fuegi, 1994, p.478-86).

13 Becher to Brecht, 5 February 1948, Bertolt Brecht Archiv, Chauseestrasse, Berlin (daqui para a frente BBA), $2118 / 04$.

14 Ver Pike (1995); Dietrich (1993); ver também Silberman (1997).

15 Ver Becher (1978, v.2, p.362-3). Ver também Dwars (1998, p.500-50). 
16 Ver Johannes R. Becher, "Schaffung eines 'Kulturbunds für die demokratische Erneuerung'”, Archiv des Intstituts für die Geschichte der Arbeiterbewegung, NL 36/734, apud Schivelbusch (1998, p.75); Silberman (1997, p.2-21).

17 Brecht tornou-se mais tarde um dos vice-presidentes da Academia (BBA, 211/66, 795/01).

18 Ver Fritz Erpenbeck, Neues Deutschland (daqui para a frente ND), 16 April 1959.

19 Ver Ernst Hermann Meyer, "Das Verhör des Lukullus", 12 March 1951, Dentsche Akademie der Künste (daqui para a frente DAK), Sing.-Nr. 564, Berlin.

20 Ver Alexander Dymschitz, "Uber die formalistische Richtung in der deutschen Malerei. Bemerkungen eines Aussenstehenden”, Tägliche Rundschau (daqui para a frente TR), 19 and 24 November 1948.

21 Ver N. Orlow, "Das Reich der Schatten auf der Bühne”, TR, Sunday, 19 November 1950, "Wege und Irrwege der Moderne", TR, 21-3 January 1951.

22 Ver Hoffmann, "Die Bedeutung der ideologischen Offensive in der Sowjetunion für Deutschland" (Einheit, v.4, n.9, p.793-4), (apud Herf, 1997, p.111-2).

23 Ver Tagung des ZK der SED, 15-17 March 1951, IfGA, ZPA IV, Blatt 2 (apud Lucchesi, 1993, p.103).

24 Ver Otto Grotewohl to Brecht, 30 April 1951, BBA, 135/19; Lucchesi (1993, p.25l).

25 Ver Käthe Rülicke, “Notiz zu Gesprächen mit Bertolt Brecht”, 13 March 1951, BBA, 1340/49, 48.

26 Trabalhos recentes sobre a insurreição de 17 de junho incluem: Knabe (2003), Eisenfeld et al. (2003) e Steininger (2003).

27 Ver Alexander Abusch, "Faust - Held oder Renegat in der deutschen Nationalliteratur?" (Sontag, 17 May 1953); Wilhelm Girnus, “Das 'Faust' - Problem und die deutsche Geschichte. Bemerkungen aus Anla $\beta$ des Erscheinens des Operntextes "Johann Faustus" von Hanns Eisler”, ND, 14 and 16 May 1953. Johanna Rudolph, ND, 28 May 1953.

28 Ver Peter Huchel, Europäische Ideen (apud Hecht, 1997, p.1061).

29 Girnus, "Das 'Faust'-Problem und die deutsche Geschichte. Bemerkungen aus Anla $\beta$ des Erscheinens des Operntextes "Johann Faustus" von Hanns Eisler", ND, 14 and 16 May 1953. Johanna Rudolph, ND, 28 May 1953.

30 Ver Bertolt Brecht, “Thesen zur Faustus-Diskussion”, Mittwochgesellschaft, DAK, 27 May 1953 (apud Bunge, 1991, p.161).

31 Cf. Suhrkamp to Brecht, 19 June 1953; BBA, 787/58.

32 Stiftung Archiv der Parteien um Massenorganisationen der DDR im Bundesarchiv, Berlin (apud GKBA, v.23, p.548).

33 Cf. "Dringlichkeit einer grossen Aussprache", 23 June 1953, ND (apud ibidem, p.250).

34 Ver Brecht, Poems 1913-1956, p.437-8; DAK, $118 / 435$.

35 Cf. "Erklärung der Deutschen Akademie der Künste. Vorschläge an die Regierung übergeben”, ND 12 July 1953. Ver também Dwars (1998, 667ff).

36 Cf. Wolfgang Harich, Hoover Institution's East German Oral History Project, 1 December 1990 (apud Heiser-Duron, s. d., p.53). 
37 Cf. Wolfgang Harich, "Es geht um den Realismus”, ND, 14 July 1953; Brecht Poems, op. cit., p.436-7.

38 Cf. Bertolt Brecht, "Kulturpolitik um die Akademie der Künste", ND, 13 August 1953, apud Brecht, Schriften III ( GKBA v.23, p.256-60).

39 Huchel (1984, p.375) retirou seu pedido de demissão em 2 de julho. Heiser-Duron (s. d., p.50-5).

40 Cf. Becher to Brecht, 24 February 1954; BBA, 832/04.

Referências bibliográficas

ABUSCH, A. Sinn und Form, v.4, 3/4, p.179-94, 1953.

ADORNO, T. Commitment. In: __. Notes on Literature III. Trans. Shierry Weber Nicholsen. Columbia, 1992.

ARENDT, H. Men in Dark Times. New York, 1968.

BECHER, J. R. Bemerkungen zu unseren Kulturaufgaben. In: Publizistik. Berlin, 1978. v.2.

BRECHT, B. Grosse kommentierte Berliner und Frankfurter Ausgabe (GKBA). Org. Werner Hecht, Jan Knopf, Werner Mittenzwei and Klaus-Detlef Müller. Berlin, Weimar, Frankfurt am Main, 1955. v.25.

. Versuche. Berlin, 1957. v.2.

. The Epic Theater and its Difficulties. In: Brecht on Theater. The Development

of an Aesthetic. New York, 1964. . Schriften zur Politik und Gesellschaft I. Berlin and Weimar, 1968a. . Stücke XIV. Berlin and Weimar, 1968b.

Briefe. Frankfurt am Main 1981.

BUNGE, H. Fragen Sie mehr über Brecht, Hanns Eisler im Gespräch. Munich, 1970.

1991.

. Die Debatte um Hanns Eisler's 'Johann Faustus. Eine Dokumentation. Berlin

DAVIES, P.; PARKER, S. Brecht, SED Cultural Policy and the Issue of authority in the Arts. The Struggle for Control of the German Academy of Arts. In: GILES, S. Bertolt Brecht. Centenary Essays. Amsterdan and Atlanta, GA, 1998.

DIETRICH, G. Politik und Kultur in der SBZ. Bern, 1993.

DWARS, J.-F. Abgrund des Widerspruchs. Das Leben des Johannes R. Becber. Berlin, 1998.

EISENFELD, B. et al. Die verdraengte Revolution. Bremen, 2003.

EISLER, H. Musik und Politik, 2 Bände. Org. Gunter Mayer. Leipzig, 1985.

ERPENBECK, F. Die Weltbühne, 18 January 1949.

FUEGI, J. Brecht \& Co. Sex, Politics and the Making of Modern Drama. New York, 1994.

GRAMSCI, A. Prison Notebooks. New York, 1971.

GRASS, G. Die Plebejer proben den Aufstand. Ein deutsches Trauerspiel. Darmstadt and Neuwied, 1966.

HAYMAN, R. Brecht. A Biography. New York, 1983.

HECHT, W. Brecht Chronik. 1898-1956. Frankfurt am Main, 1997. 
HEISER-DURON, M. Brecht Political and Cultural Dilemma in the Summer of 1953. Communications from the International Brecht Society, v.30, n.1 e 2, p.50-2, s.d.

HUCHEL, P. Werke II. Frankfurt, 1984.

JAEGER, M. Sozialliteraten. Funktion und Selbsverständnis der Schriftsteller in der DDR. Düsseldorf, 1973.

KNABE, H. 17.Juni 1953. Ein deutscher Aufstand. Munich, 2003.

KNOPF, J. Brecht Handbuch. Lyrik, Prosa, Schriften. Stuttgart, 1984.

LUCCHESI, J. Das Verhör in der Oper. Berlin, 1993.

LUKÁCS, G. Aus der Not eine Tugent. In: Marxismus und Literatur. Reinbek bei Hamburg, 1969. v.2.

. Reportage or Portrayal? In: Essays on realism. Cambridge, MA, 1981.

LUNN, E. Marxism and modernism. Berkeley, CA, 1982.

MITTENZWEI, W. Das Leben des Bertolt Brecht oder Der Umgang mit den Welträtseln. Berlin and Weimar, 1986. v.1-2.

OSTERMANN, C. (Org.) Uprising in East Germany, 1953. Budapest and New York, 2001.

PIKE, D. Lukács and Brecht. Chapel Hill, NC, 1985.

. The Politics of Culture in Soviet-Occupied Germany. Stanford, CA, 1995.

RECHTIEN, R. Relations of Production? Christ Wolf's Extended Engagement with the Legacy of Bertolt Brecht. In: GILES, S. Bertolt Brecht. Centenary Essays. Amsterdan and Atlanta, GA, 1998.

RILLA, P. Berliner Zeitung, 18 April 1950.

SCHIVELBUSCH, W. In a Cold Crater. Cultural and Intellectual Life in Berlin, 19451948. Berkeley and Los Angeles, CA, 1998.

SILBERMAN, M. Problematizing the "Socialist Public Sphere". Concepts and Consequences. In: What Remains? East German Culture and the Postwar Public. Washington DC, 1997.

. The Threepenny Lawsuit. A Sociological Experiment. In: Bertolt Brecht on Film and Radio. London, 2000.

STEININGER, R. 17 Juni 1953. Der Anfang vom langen Ende der DDR. Munich, 2003.

WILLETT, J. (Ed.) Bertolt Brecht Letters. Trans. Ralph Manheim. New York, 1990.

ZUCKMAYER, K. Als wär's ein Stück von mir. Frankfurt, 1966.

Mark W. Clark é professor associado e chefe do Departamento de História e Filosofia da University of Virginia's College, em Wise. Ele ensina História Européia Moderna e é autor de vários artigos sobre a vida cultural alemã no século XX, e atualmente prepara um livro, Beyond Catastrophe. German Intellectuals and Cultural Renewal after World War II, 1945-1955. Atualmente trabalha com uma história intelectual comparativa da Alemanha e da Itália no período após 1945.

Tradução de Lenita Rimoli Esteves e Almiro Pisetta. O original em inglês - Heros or Villain? Bertold Brecht and the Crisis Surrounding June 1953 - encontra-se à disposição do leitor no IEA-USP para eventual consulta. 